\title{
A mobile differential absorption lidar to measure sub-hourly fluctuation of tropospheric ozone profiles in the Baltimore-Washington, D.C. region
}

\author{
J. T. Sullivan ${ }^{1,2}$, T. J. McGee $^{3}$, G. K. Sumnicht ${ }^{4}$, L. W. Twigg ${ }^{4}$, and R. M. Hoff ${ }^{1,2}$ \\ ${ }^{1}$ Department of Atmospheric Physics, University of Maryland Baltimore County (UMBC), Baltimore, MD, USA \\ ${ }^{2}$ Joint Center for Earth Systems Technology (JCET), Baltimore, MD, USA \\ ${ }^{3}$ Code 614.0, NASA Goddard Space Flight Center, Greenbelt, MD, USA \\ ${ }^{4}$ Science Systems and Applications Inc., Lanham, MD, USA
}

Correspondence to: J. T. Sullivan (johnsullivan@umbc.edu)

Received: 1 April 2014 - Published in Atmos. Meas. Tech. Discuss.: 30 April 2014

Revised: 1 September 2014 - Accepted: 14 September 2014 - Published: 15 October 2014

\begin{abstract}
Tropospheric ozone profiles have been retrieved from the new ground-based National Aeronautics and Space Administration (NASA) Goddard Space Flight Center TROPospheric OZone DIfferential Absorption Lidar (GSFC TROPOZ DIAL) in Greenbelt, MD $\left(38.99^{\circ} \mathrm{N}, 76.84^{\circ} \mathrm{W}\right.$, $57 \mathrm{~m}$ a.s.l.), from $400 \mathrm{~m}$ to $12 \mathrm{~km}$ a.g.l. Current atmospheric satellite instruments cannot peer through the optically thick stratospheric ozone layer to remotely sense boundary layer tropospheric ozone. In order to monitor this lower ozone more effectively, the Tropospheric Ozone Lidar Network (TOLNet) has been developed, which currently consists of five stations across the US. The GSFC TROPOZ DIAL is based on the DIAL technique, which currently detects two wavelengths, 289 and $299 \mathrm{~nm}$, with multiple receivers. The transmitted wavelengths are generated by focusing the output of a quadrupled Nd:YAG laser beam $(266 \mathrm{~nm})$ into a pair of Raman cells, filled with high-pressure hydrogen and deuterium, using helium as buffer gas. With the knowledge of the ozone absorption coefficient at these two wavelengths, the range-resolved number density can be derived. An interesting atmospheric case study involving the stratospherictropospheric exchange (STE) of ozone is shown, to emphasize the regional importance of this instrument as well as to assess the validation and calibration of data. There was a low amount of aerosol aloft, and an iterative aerosol correction has been performed on the retrieved data, which resulted in less than a $3 \mathrm{ppb}$ correction to the final ozone concentration. The retrieval yields an uncertainty of $16-19 \%$ from 0 to $1.5 \mathrm{~km}, 10-18 \%$ from 1.5 to $3 \mathrm{~km}$, and $11-25 \%$ from 3 to
\end{abstract}

$12 \mathrm{~km}$ according to the relevant aerosol concentration aloft. There are currently surface ozone measurements hourly and ozonesonde launches occasionally, but this system will be the first to make routine tropospheric ozone profile measurements in the Baltimore-Washington, D.C. area.

\section{Introduction}

Tropospheric ozone above the ground level has been historically difficult to measure directly due to its relatively short lifetime and nonlinear formation (Stevenson et al., 2013). It is an important greenhouse gas, pollutant, and source of $\mathrm{OH}$ radicals. Its contribution to global warming from the preindustrial era to the present is regarded as the third-most important, following those of carbon dioxide $\left(\mathrm{CO}_{2}\right)$ and methane $\left(\mathrm{CH}_{4}\right)$ (IPCC, 2007). Ozone is also toxic to humans and vegetation because it begins oxidizing biological tissue and causes harmful respiratory effects in instances of long exposure (McDonnell et al., 1999). Tropospheric ozone concentrations within the planetary boundary layer (PBL) in the Baltimore-Washington, D.C. area are typically dominated by photochemistry with local ozone precursor emissions, but within the free troposphere there are other source classifications such as (1) stratospheric-tropospheric exchange (STE), (2) advection from upwind sources, and (3) regional redistribution from convection and/or lightning (Thompson et al., 2008). 
During an STE event, large concentrations of ozone are exchanged between the stratosphere and the troposphere often caused by an unusually low polar or subtropical jet stream (Langford, 1999; Stohl et al., 2003). A recent analysis of summertime tropospheric ozone profiles in the BaltimoreWashington, D.C. area showed that STE accounted for greater than $50 \%$ of the free-tropospheric ozone column on $17 \%$ of days sampled (Yorks et al., 2009). The second source of ozone in the free troposphere occurs when ozone is transported aloft or advected with varying layer thickness and concentration downwind of the major ozone precursor production sites, potentially resulting in an ozone exceedance for rural and less populated areas (NCADAC, 2013). The subsidence of the ozone layer aloft has been shown to cause air quality issues for a region that may not have actually produced the ozone or its precursors (Langford et al., 2010). The third source of ozone in the free troposphere is not a primary source, but rather the ozone precursor $\mathrm{NO}_{\mathrm{x}}$ is induced by lightning flashes, which accounts for $5-10 \%$ of the overall tropospheric ozone budget (Schumann and Huntrieser, 2007; Yuan et al., 2012).

With such dynamic sources of ozone in the troposphere, it is essential to monitor the vertical distribution of tropospheric ozone. Although the vertical location of atmospheric trace gases are remotely monitored by satellites, such as $\mathrm{CO}_{2}$ by the Atmospheric Infrared Sounder (AIRS), acquiring these measurements in the ultraviolet (UV) regime, especially near the surface, is difficult due to the optically thick stratospheric ozone layer strongly attenuating the signal (Fishman et al., 1990). Ozone profiles from the Tropospheric Emission Spectrometer (TES) and the Ozone Mapping Instrument (OMI) have been reported, but have usually required a large amount of prior knowledge and/or ancillary satellites (such as NASA's Microwave Limb Sounder (MLS)) are needed to determine the residual amount of ozone in the troposphere (Ziemke et al., 2006; Bowman et al., 2002). Additionally, total and tropospheric columns may be retrieved from infrared radiance spectra recorded by the Infrared Atmospheric Sounding Interferometer (IASI) (Boynard et al., 2009). Even if the tropospheric ozone column or profile is reported, it may be a seasonal or monthly mean, in which the variability of ozone gives the profiles marginal statistical value (Thompson et al., 2003). For ozone profiles that are reported for a direct overpass, due to the large footprint of the satellite, this method may not be able to resolve small-scale fluctuations of tropospheric ozone concentration, especially during quickly evolving pollution episodes. By monitoring and analyzing tropospheric ozone from a ground-based instrument, such as an ozone lidar, the signal is not attenuated via stratospheric ozone and the tropospheric ozone concentrations can be detected at a much higher temporal and vertical resolution.

For these reasons, the National Aeronautics and Space Administration (NASA) Goddard Space Flight Center TROPospheric OZone DIfferential Absorption Lidar (GSFC
TROPOZ DIAL) has been developed in a transportable trailer to take routine measurements of tropospheric ozone near the Baltimore-Washington, D.C. area (Greenbelt, MD $38.99^{\circ} \mathrm{N}, 76.84^{\circ} \mathrm{W}, 57 \mathrm{~m}$ a.s.1.) and various campaign locations. This instrument has been developed as part of the ground-based Tropospheric Ozone Lidar NETwork (TOLNet), which currently consists of five stations across the United States (http://www-air.larc.nasa.gov/missions/ TOLNet/). The primary purpose of the instruments within TOLNet is to provide regular, high-fidelity profile measurements of ozone within the troposphere, particularly the changing ozone dynamics and laminae inside the PBL. The network will also serve to validate the upcoming GEOstationary Coastal and Air Pollution Events (GEO-CAPE) mission, scheduled to be launched in the 2020 time frame.

Another objective of TOLNet is to identify a brassboard ozone lidar instrument that would be suitable to populate a network to address the needs of NASA, the Environmental Protection Agency (EPA), and the National Oceanic and Atmospheric Administration (NOAA) air-quality scientists and managers who increasingly express a desire for ozone profiles. Although other countries have been reporting lidar-based tropospheric ozone profiles for many years, these semi-routine observations have never been attempted in the United States.

Similar ground-based instruments have been developed within TOLNet (McDermid et al., 2002; Alvarez et al., 2011; Kuang et al., 2013), but the GSFC TROPOZ DIAL is the first to measure ozone profiles in the mid-Atlantic region. Aside from the site at the Jet Propulsion Laboratory's Table Mountain Facility (JPL's TMF), this is the only instrument within TOLNet currently utilizing high-pressure stimulated Raman scattering (SRS) cells for wavelength generation (Haner and McDermid, 1990). Because the remote JPL TMF site is in the Angeles National Forest at an altitude of $2.3 \mathrm{~km}$ a.s.l., the GSFC TROPOZ DIAL will be the first system to use this SRS technique to routinely determine quantitative ozone profiles near sea level directly in an urban environment within the United States.

There have been successful DIAL instruments that have utilized the ground-based monitoring method, dating back to the 1970s, with a focus on water vapor (Browell et al., 1979) and temperature profiles (Murray et al., 1980). These concepts were then successfully modified and demonstrated to yield accurate results for ozone detection (Megie et al., 1977; Uchino et al., 1978; Megie et al., 1985; Browell, 1989), with specific emphasis on monitoring and maintaing a historic record of ozone trends in the stratosphere (Pelon and Mégie, 1982; Godin et al., 1989; McDermid et al., 1991; McGee et al., 1993, 1995; Proffitt and Langford, 1997; Steinbrecht et al., 2006).

Previous work also exists of tropospheric ozone lidar measurements that have used a similar method of Raman wavelength generation (Ancellet et al., 1989; Stefanutti et al., 1992; Uthe et al., 1992; Uchino et al., 2014), but each of 
these systems, including the TROPOZ, has been constructed to investigate a different scientific question. Similar instruments have been deployed as nadir-viewing airborne systems in previous NASA (Browell et al., 1983, 1987, 1993) and NOAA (Senff et al., 2010) missions. The TROPOZ has been developed as a ground-based transportable instrument as opposed to an airborne instrument because past efforts to predict and monitor high levels of ozone in large cities, such as Houston (Banta et al., 2005) and Los Angeles (Menzies and Shumate, 1978), from airborne missions have been hampered by the lack of information of the temporal evolution of the ozone profile and the extent and height of vertical mixing in the first few kilometers above the surface (Morris et al., 2010).

At the surface, in situ UV analyzers and photometers are the most common form of ozone monitors and are usually accurate to within $5 \%$ of the known value (Puzak, 1987) and can report values with very high temporal resolution. The EPA has set up a network of surface ozone monitoring and detection that covers a large spatial and temporal region in the last few decades (Demerjian, 2000). These ozone concentrations are typically reported in hourly average values or $8 \mathrm{~h}$ average values and are useful for analyzing surface trends in ozone. As mentioned earlier, ozone can be transported aloft and advected, preventing the surface monitors from truly representing the ozone distribution in that region. The vertical distribution of ozone is an important parameter in analyzing daily and seasonal trends and events that surface monitors cannot provide. If there is a dramatic change in ozone at the surface that cannot be explained with the in situ data, it is essential to analyze the vertical profile of ozone above the surface as a function of time (Oltmans and Komhyr, 1986).

The common historical method for vertical ozone detection is sending a balloon-borne electrochemical concentration cell (ECC) instrument through the atmosphere, but this may not be on the continuous scale that is necessary to fully characterize small-scale fluctuations in ozone. The ECC profiles ozone with a $100 \mathrm{~m}$ vertical resolution from the surface to a balloon-dependent altitude, in which $35 \mathrm{~km}$ is the desired balloon-bursting altitude (Komhyr et al., 1995; Oltmans et al., 1996; Newchurch et al., 2003). Many research groups have long-term records of ozone soundings using this method, and small correction factors may be necessary depending on the manufacturer or the cathode solution implemented. For measurement of ozone below $30 \mathrm{~km}$ with these correction factors, ECC sondes yield a precision better than $\pm(3-5) \%$ and an accuracy of about $\pm(5-10) \%$ (Smit et al., 2007).

Due to complex formation and transport of ozone it is typically necessary to measure for extended periods of time to fully characterize an ozone pollution episode, which favors a continuous measurement as opposed to an isolated profile or several profiles. Using lidar techniques in mostly cloudfree conditions, it is possible to measure the continuous vertical distribution of the dynamic atmosphere by detecting the return signal as a function of altitude. A stationary, continuous time series of vertical profile measurements can be obtained more cost effectively with a DIAL instrument such as that described in this paper than with the launch of multiple ozonesondes (Pelon and Mégie, 1982; Trickl et al., 2003; Galani et al., 2003; Trickl et al., 2011).

The metropolitan area surrounding the GSFC TROPOZ DIAL is affected by locally produced pollutants from highly populated urban areas as well as ozone precursors advected from the Ohio River Valley/Appalachian mountain regions. Depending on the meteorological conditions, these pollutants can cause non-localized unfavorable air quality issues for smaller rural areas as well as the Chesapeake Bay watershed to the south and east. If the eastward propagation of pollutants is inhibited, a stagnant air mass over the BaltimoreWashington, D.C. area results and is the ideal condition for a high-pollution episode (Delgado et al., 2014). During these forecasted high-ozone episodes, the GSFC TROPOZ DIAL has been designed to operate as a continuous monitoring instrument and has sustained multi-day uninterrupted observations. The mid-Atlantic region displays a moderate amount of seasonal ozone variability with the highest concentrations occurring in the late July time period (Lehman et al., 2004). Because of this, during fall and winter seasons, the TROPOZ focuses its observations on monitoring ozone in the free troposphere and the aforementioned source contributions, such as STE. This paper investigates the steps necessary to construct the GSFC TROPOZ DIAL in order to retrieve and better characterize the vertical distribution of tropospheric ozone in the Baltimore-Washington, D.C. area, in which a regionally important validation test case of an unusually low tropopause - resulting in the exchange of high amounts of ozone between the stratosphere and the lower free troposphere, or STE - is presented and analyzed.

\section{The DIfferential Absorption Lidar (DIAL) method}

Fundamentally, the DIAL method relies on the fact that the ozone molecule has a strongly varying spectral absorption curve in ozone's Hartley band region. The structureless nature of the absorption spectrum of ozone in this region allows for a minimum spacing of $2 \mathrm{~nm}$ between on and off resonant wavelengths (Milton et al., 1998) for accurate profiling of ozone throughout the free troposphere. Although the wavelengths used with this instrument are spaced further apart $(10 \mathrm{~nm})$, they have the advantage of being generated very reliably as opposed to previously used dye laser (Pelon and Mégie, 1982; Browell, 1983; Megie et al., 1985; Kuang et al., 2011), excimer laser (Uchino et al., 1983; de Schoulepnikoff et al., 1997; Veselovskii and Barchunov, 1999), and tunable laser cavity (Fix et al., 2002; Fromzel et al., 2010; Senff et al., 2010) systems. Figure 1, adapted from Malicet et al. (1995), illustrates the ozone absorption cross section $\left(\sigma_{\mathrm{O}_{3}}\right)$ and the TROPOZ wavelengths that were generated for the 
large gradient in ozone absorption $\left(\Delta \sigma_{\mathrm{O}_{3}}\right)$, which will yield usable atmospheric information. Different colors in the figure correspond to the temperature dependence of the absorption cross sections. The DIAL method is optimized when the ratio of the difference in the ozone absorption cross section to the difference in wavelength $\left(\Delta \sigma_{\mathrm{O}_{3}} / \Delta \lambda\right)$ is maximized within certain atmospheric constraints (Pelon and Mégie, 1982; Measures, 1983).

Retrieval of useful ozone profiles during daytime hours requires the instrument to utilize wavelengths less than $300 \mathrm{~nm}$ (Pelon and Mégie, 1982) to avoid saturation of the detectors from sunlight, and to maximize the signal-to-noise ratio (SNR) of the system (Megie et al., 1985; Ancellet et al., 1989; Browell, 1989; Proffitt and Langford, 1997; Milton et al., 1998). Although the ozone absorption curve continues to rise sharply as the wavelength decreases (increasing the $\Delta \sigma_{\mathrm{O}_{3}} / \Delta \lambda$ ), the signal is attenuated much too strongly to yield usable information above the PBL. Essentially, shorter wavelengths are absorbed so strongly by ozone that the return signal would be unusable above the PBL, especially during pollution episodes. These issues constrain the choice of wavelengths to between 280 and $300 \mathrm{~nm}$. This ensures the system has a large enough signal to easily retrieve ozone profiles through the PBL and into the lower free troposphere (Papayannis et al., 1990).

From Fig. 1, $288.9 \mathrm{~nm}$ has an absorption cross section nearly 3 times as large as $299.1 \mathrm{~nm}$, and both wavelengths can be generated reliably (and much more cost-effectively than dye or tunable cavity lasers) using SRS in high-pressure Raman cells (Megie et al., 1985; Komine, 1986; Milton et al., 1998; Ancellet et al., 1989; Haner and McDermid, 1990; Papayannis et al., 1990; Tzortzakis et al., 2004). The transmitted wavelengths are generated by focusing the output of two frequency-quadrupled Neodymium-doped yttrium aluminum garnet (Nd:YAG) laser beams $(266 \mathrm{~nm})$, each into a pair of high-pressure Raman cells, one filled with hydrogen and the other deuterium. Both cells have been optimized using helium as a buffer gas. The more absorbing wavelength, at $288.9 \mathrm{~nm}$, is called the "on" wavelength; the less absorbing wavelength, at $299.1 \mathrm{~nm}$, is called the "off" wavelength. This process of SRS and the generation of the necessary DIAL wavelengths will be discussed more in the Experimental Construction section of the paper. Because the inelastic Raman conversion is done prior to transmission into the atmosphere, and detection of atmospheric scattering is done at these same transmitted wavelengths, the TROPOZ retrieval uses an elastic technique. With the knowledge of the ozone absorption coefficient at these two wavelengths, the rangeresolved ozone number density can then be derived with the DIAL equation.

\subsection{The DIAL equation}

The DIAL equation (Measures, 1983; Browell et al., 1985; Milton and Woods, 1987; Papayannis et al., 1990) can be

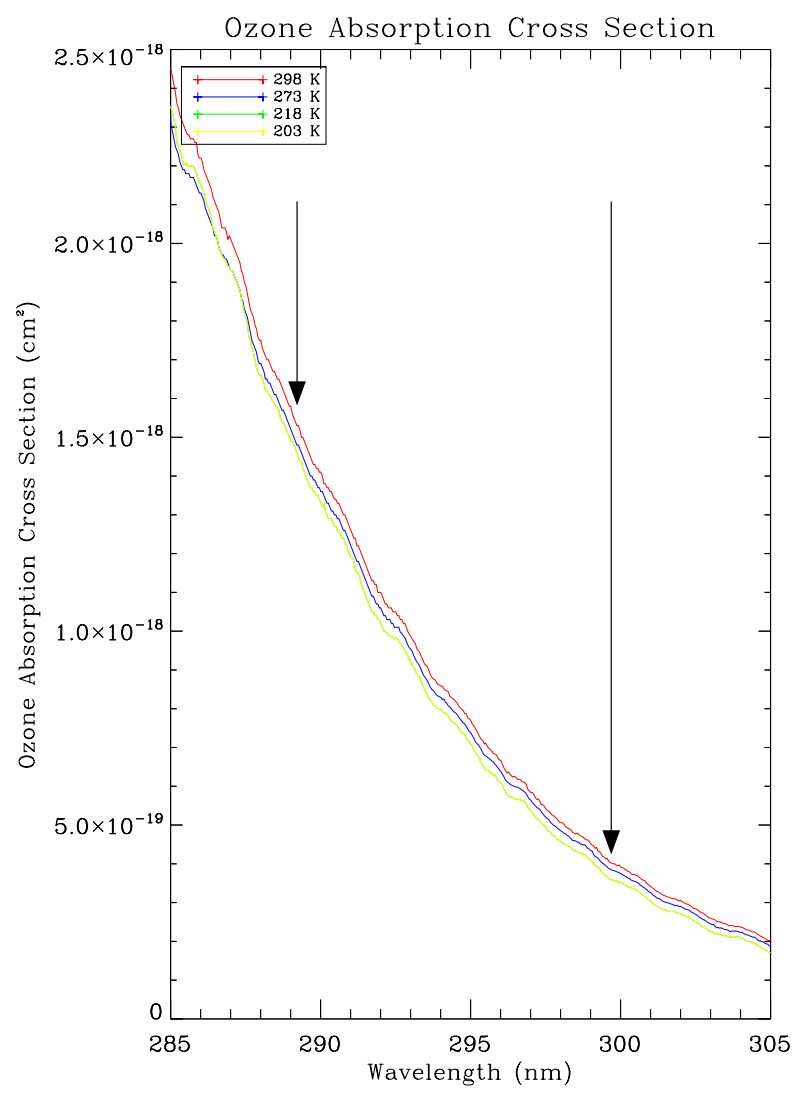

Figure 1. The spectral dependence of the ozone absorption cross section in the UV. The more absorbing wavelength, at $288.9 \mathrm{~nm}$, is called the "on" wavelength; the less absorbing wavelength, at $299.1 \mathrm{~nm}$, is called the "off" wavelength. (Source: Malicet et al., 1995)

written in terms of the ozone number density as

$$
\begin{aligned}
N_{\mathrm{O}_{3}}(r)= & \frac{1}{2 \Delta \sigma_{\mathrm{O}_{3}}} \frac{d}{d r} \ln \left[\frac{P_{\text {on }}(r)}{P_{\text {off }}(r)} \frac{\beta_{\text {off }}(r)}{\beta_{\text {on }}(r)}\right] \\
& +\frac{\Delta \alpha_{\text {atmosphere }}(r)}{\Delta \sigma_{\mathrm{O}_{3}}}
\end{aligned}
$$

where $N_{\mathrm{O}_{3}}$ is the ozone number density and $\Delta \sigma_{\mathrm{O}_{3}}$ is the difference in corresponding ozone absorption cross sections taken for the two wavelengths in Fig. 1. The return signal, atmospheric backscatter coefficient, and atmospheric extinction received from range $r$ at either the on or off wavelength are denoted as $P, \beta$, and $\alpha$, respectively. The term $\Delta \alpha_{\text {atmosphere }}$ is the difference in the extinction properties of the atmosphere between the two DIAL wavelengths. This includes spectral differences in Rayleigh scattering, Mie scattering, aerosols, and other interfering gases that have similar absorption properties in the on and off wavelengths.

Lidar return signals are not recorded or analyzed as continuous functions, but rather as values in discrete range bins, $\Delta r$. It is then possible to write the discrete DIAL equation (Megie et al., 1985) in terms of the range bins specified 
and additional extinction corrections from the Rayleigh atmosphere $\left(\alpha_{\mathrm{mol}}\right)$, aerosols $\left(\alpha_{\mathrm{aer}}\right)$, and other interfering gases $\left(\alpha_{\mathrm{IG}}\right)$ as

$$
\begin{aligned}
N_{\mathrm{O}_{3}}= & \frac{1}{2 \Delta \sigma_{\mathrm{O}_{3}} \Delta r} \ln \left(\frac{P_{\mathrm{off}}(r+\Delta r)}{P_{\mathrm{off}}(r)} \frac{P_{\mathrm{on}}(r)}{P_{\mathrm{on}}(r+\Delta r)}\right. \\
& -C)-D,
\end{aligned}
$$

where

$C=\frac{\beta_{\text {off }}(r+\Delta r)}{\beta_{\text {off }}(r)} \frac{\beta_{\text {on }}(r)}{\beta_{\text {on }}(r+\Delta r)}$

and

$D=\frac{\Delta \alpha_{\mathrm{mol}}}{\Delta \sigma_{\mathrm{O}_{3}}}+\frac{\Delta \alpha_{\mathrm{aer}}}{\Delta \sigma_{\mathrm{O}_{3}}}+\frac{N_{\mathrm{IG}} \Delta \alpha_{\mathrm{IG}}}{\Delta \sigma_{\mathrm{O}_{3}}}$.

Equation (2) is referred to as the DIAL equation and is of great interest because it is a self-calibrating technique that can determine the number density of ozone with only the known ozone absorption cross sections and the backscattered signal returned to each detector.

The correction term $C$ is due to the difference in return signal at each wavelength. This can be a combination of Rayleigh scattering and aerosol scattering if aerosols are present. Rayleigh extinction (which is the first term in $D$ ) is typically based on a $\lambda^{-4}$ scaling, which develops a slight difference in the molecular extinction that is fairly easy to interpolate (Measures, 1983) with additional meteorological terms for corrections given by a reference standard atmosphere (US Standard, 1976). With the knowledge of the Rayleigh extinction values, the Rayleigh backscatter term in $C$ is computed using the assumed Rayleigh phase function.

The second term in $D$ is due to the presence of aerosols and the wavelength dependence of the aerosol extinction coefficient. Depending on the optical properties of the aerosols in the atmosphere during the measurement, this value can change as well, leading to an additional necessary correction (Bösenberg, 1998). In most cases the correction for the additional backscattered light from aerosol gradients to the detector is much larger than the necessary correction for the aerosol extinction correction at these wavelengths (Weitkamp, 2006). The aerosol correction term in $D$ is determined using an iterative method in which, using various valid assumptions, it is possible to determine the necessary ozone number density correction. The correction is then coupled with an assumed lidar ratio to determine the correction factor due to aerosols in $C$. This will be discussed further in the Data processing section of this paper.

The third term in $D$ is due to the interference of external interfering gases (IG), such as sulfur dioxide $\left(\mathrm{SO}_{2}\right)$ and nitric oxide $\left(\mathrm{NO}_{2}\right)$. In the wavelength region used for the present work, these gases have relatively similar absorption cross sections to ozone, but the number density $\left(N_{\mathrm{IG}}\right)$ is typically so low that the contribution it makes to the calculation of $D$ is small compared to that from the Rayleigh or aerosol terms (Kovalev and Eichinger, 2004).

\section{Experimental construction}

\subsection{Raman cells and stimulated Raman scattering (SRS)}

As mentioned before, it was advantageous to move toward the use of a stable Nd:YAG laser, with the fourth harmonic frequency $(266 \mathrm{~nm})$ pumping a pair of high-pressure Raman cells to generate the transmitted DIAL frequencies. This method, SRS (Mollenauer et al., 1992), is a direct two-photon, third-order nonlinear optical process that results in inelastic light scattering without the requirement of phase matching (Measures, 1983). This process is efficient for gases such as hydrogen and deuterium because they have high-frequency vibrational modes and narrow spectral linewidths (Shen and Bloembergen, 1965).

In order to maximize the generation of the first Stokes frequency, a low numerical aperture pumping geometry and a long optical interaction length (Carlsten et al., 1984) have been established, which is the reason for the length of the Raman cells $(1.8 \mathrm{~m})$ and the focal lengths $(f=1 \mathrm{~m})$ of the lenses. Because this process is a photon-to-photon conversion method, it is also favorable to have the largest volume available to increase efficiency of the SRS (Falsini et al., 1985).

For this to be an efficient technique, the steady-state gain (Haner and McDermid, 1990; Tzortzakis et al., 2004) must be at an appropriate threshold level to induce the first-order Stokes frequencies, while suppressing higher-order frequencies. A straightforward method for optimizing the steadystate gain is to add a buffer gas, such as helium, which suppresses higher orders of unwanted Stokes frequencies (Stefanutti et al., 1992); broadens the Raman full line width (Murray and Javan, 1972; and reduces collision effects, motional narrowing, and four-wave matching (Witkowicz and May, 1976; Dion and May, 1973).

\subsection{Raman cell characterization}

There are multiple discussions of the method of using a Nd:YAG laser and Raman cells to produce appropriate wavelengths for ozone detection (Haner and McDermid, 1990; Papayannis et al., 1990; de Schoulepnikoff et al., 1997; Ancellet and Ravetta, 1998; Heese et al., 2001), which were the starting point for the empirical Raman tests that were performed to optimize each Raman cell. Although higher photon conversion efficiencies with helium as a buffer gas with a fixed laboratory instrument have been achieved (Tzortzakis et al., 2004), the sensitivity of the photon conversion efficiency on laser beam characteristics - such as pump beam diameter, laser repetition rate, pulse energy, and confocal beam parameter entering each Raman cell - is complex enough to warrant further characterization tests. Unlike other instruments described in the literature, this instrument is housed inside a transportable trailer, which has limited the optical 


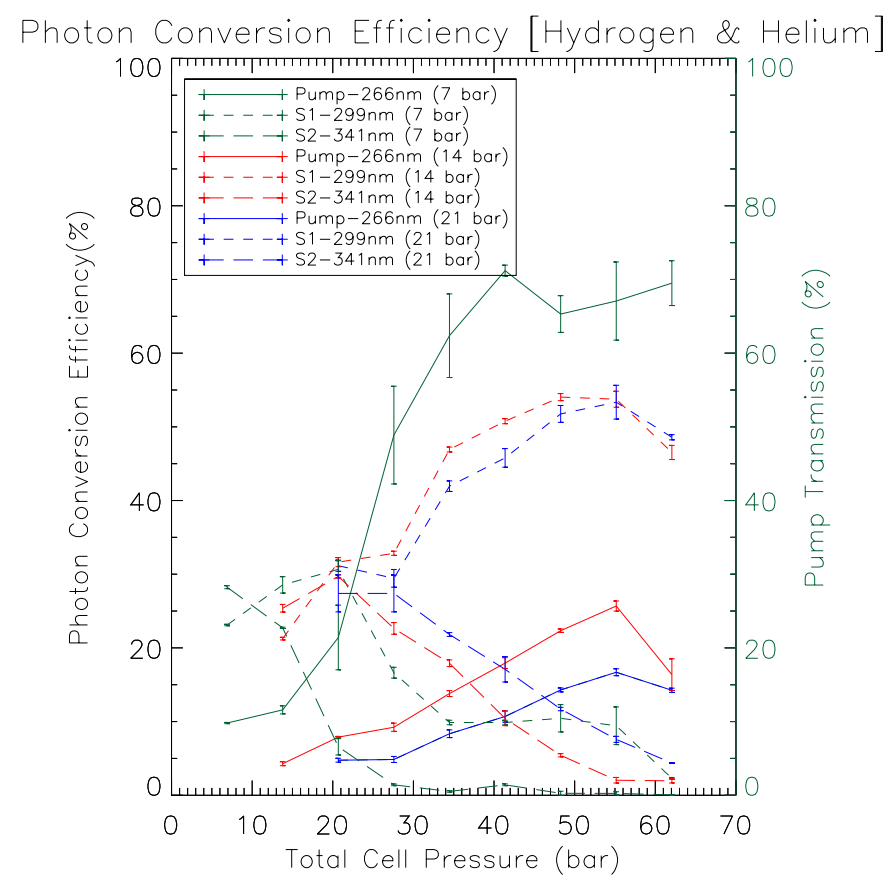

Figure 2a. Photon conversion efficiency of hydrogen as a function of total Raman cell pressure. The experiment was done with multiple partial pressures of hydrogen and helium; the most efficient pressure combination of S1 was chosen for the GSFC TROPOZ DIAL. The pressures indicated in the legend are for the partial pressures of the Raman active gas. The uncertainty bars represent one standard deviation in the measurements.

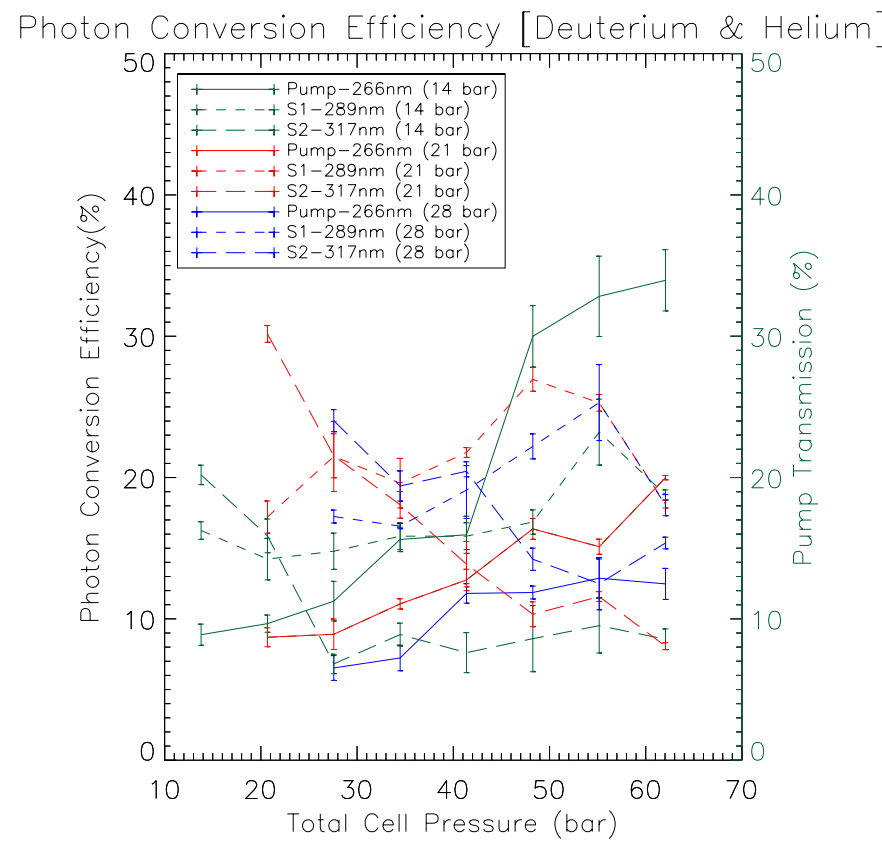

Figure 2b. The experiment repeated for the multiple pressure combinations in the deuterium Raman cell. interaction length of the Raman cells to $1.8 \mathrm{~m}$. Due to these constraints, the Raman cells were completely designed and fabricated in-house for the specific application for use in the GSFC TROPOZ DIAL.

The simplest way to analyze the photon efficiency was to adapt a dispersive Pellin-Broca prism to separate the wavelengths into discrete spots and subsequently view the beam with a fluorescent card. This provided the ability to qualitatively determine which pressure combinations suppressed higher-order Stokes shifts and which magnified higher orders. Power measurements of the beams produced by the various Stokes shifts then allowed a quantitative selection of the optimal partial pressures for each of the Raman active gases. Because this is a direct two-photon conversion process from the pump to the respective first Stokes, it was necessary to obtain a baseline for photon conversion by measuring the power of the pump photons, at $266 \mathrm{~nm}$, passing through an evacuated cell.

The empirical results for hydrogen and deuterium are shown in Fig. 2a and b. These plots are shown as photon conversion efficiency (left $y$ axis), residual pump transmission (right $y$ axis), and the total cell pressure ( $x$ axis). Due to safety concerns regarding the design of the Raman cells, the maximum pressure tested was required to be under 70 bar. Multiple power measurements were taken, and each data point corresponds to the mean with uncertainty bars of one standard deviation. Initially, power measurements were made without a buffer gas, but the photon conversion efficiencies were so low (10\% or less) that they are not reported in this figure. Once the buffer gas was introduced into the Raman cell, the efficiencies began to improve. The three colors in Figure $2 \mathrm{a}$ and $\mathrm{b}$ correspond to three different pressure combinations in each cell. The line style corresponds to the wavelength of interest that was measured, which was the pump (PUMP), the first Stokes (S1), or the second Stokes (S2).

For example, in Fig. 2a the red curves correspond to a partial pressure of 14 bar of hydrogen in which the Raman cell is incrementally filled with helium to 62 bar. The solid line is the pump wavelength, which steadily grew in the experiment as the partial pressure increased. The dotted line is the S1, which grew steadily but dropped after a total cell pressure of 48 bar. The dashed line S2 slowly decreased throughout the experiment. From these results it can be inferred that an increasing amount of buffer gas will suppress the the second Stokes wavelength and increase the output power of the first Stokes and residual pump wavelengths.

After these tests were completed, it was determined that a pressure combination of 14 bar $\mathrm{H}_{2}-42$ bar He would be the most efficient (53\%). Because $266 \mathrm{~nm}$ will hopefully be used for future work, it was important to maintain some residual amount of the transmitted pump beam. A similar process was completed for the deuterium cell, for which the pressure combination of 21 bar $D_{2}-35$ bar He would be the most efficient $(27 \%)$. The difference between the Raman cell efficiencies between the two Raman media can be largely attributed 


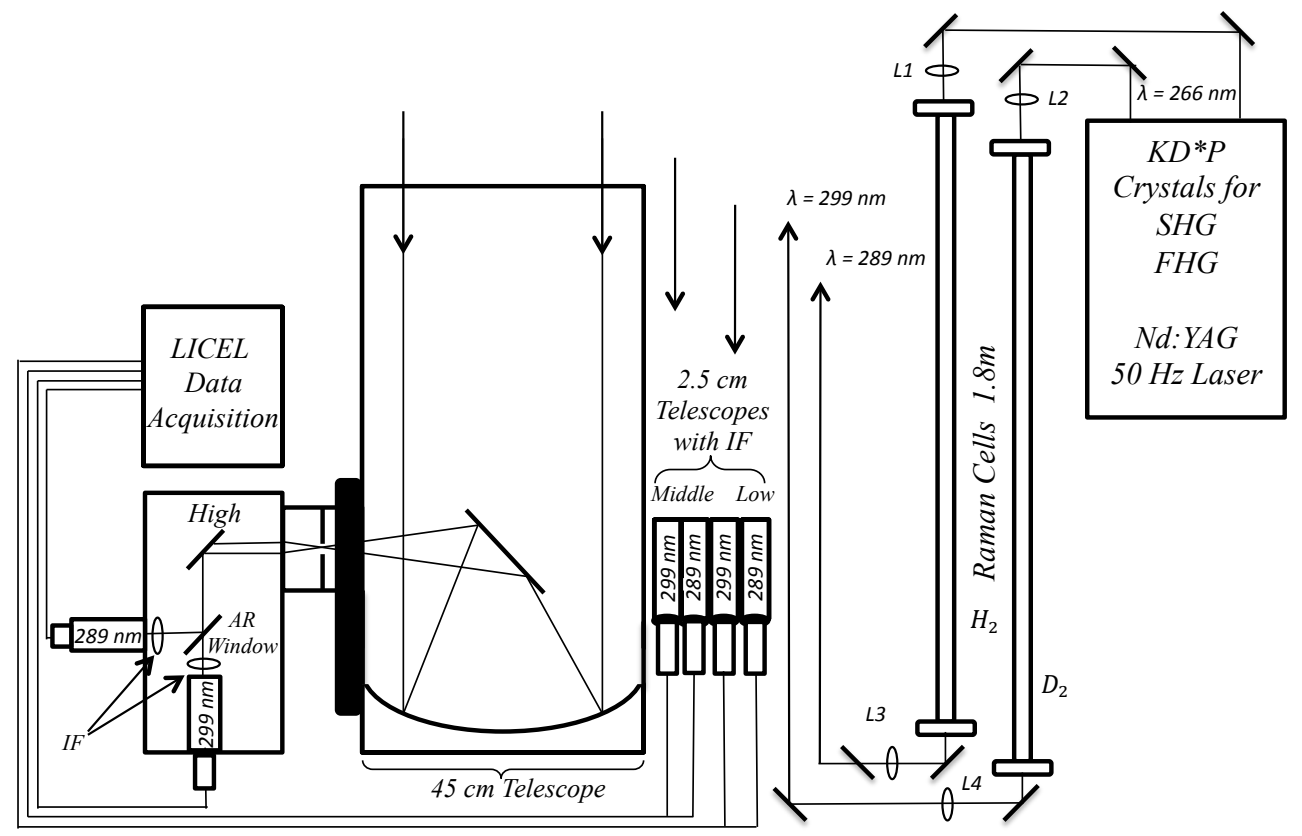

Figure 3. The experimental schematic that includes the $50 \mathrm{hz} \mathrm{Nd:YAG} \mathrm{laser,} \mathrm{steering} \mathrm{optics,} \mathrm{Raman} \mathrm{cells,} \mathrm{near-field} \mathrm{smaller} \mathrm{telescopes,} \mathrm{main}$ telescope, and detection packages.

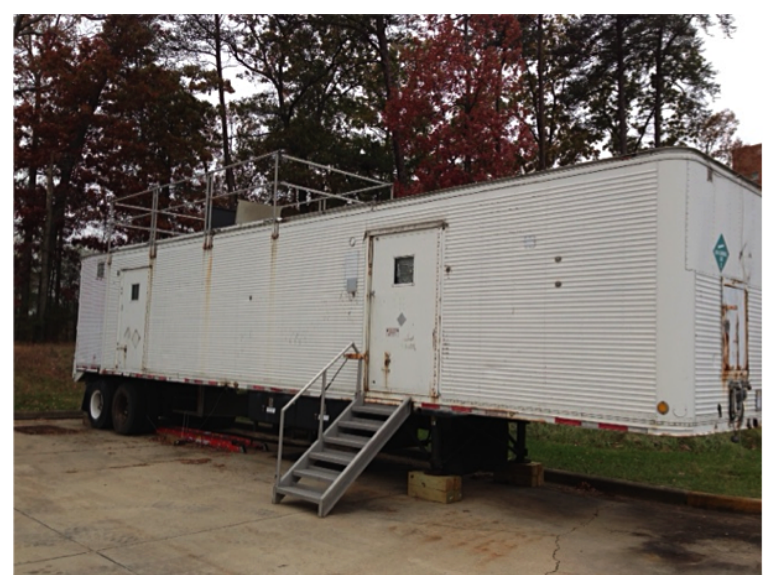

Figure 4. The $13 \mathrm{~m}$ trailer that houses the GSFC TROPOZ DIAL system. The hatch doors are open to transmit the DIAL wavelengths into the atmosphere.

to the fact that the hydrogen Raman scattering cross section $\left(\frac{\mathrm{d} \sigma}{\mathrm{d} \omega}\right)$ is nearly twice as large as the deuterium scattering cross section (Murray and Javan, 1972; Haner and McDermid, 1990).

\subsection{System description}

The schematic of the GSFC TROPOZ DIAL system with the hydrogen $\left(\mathrm{H}_{2}\right)$ and deuterium $\left(\mathrm{D}_{2}\right)$ Raman cells installed in a portable $13 \mathrm{~m}$ trailer is depicted in Fig. 3, and an image of the trailer is in Fig. 4 below. Transportable lidar systems have produced comparable results to stationary laboratories and can relocate if an event of interest arises (McGee et al., 1991).

A Spectra Physics Quanta-Ray pulsed Nd:YAG laser has been optimized with two independent parallel laser cavities. These are each composed of an oscillator/preamplifier with $10 \mathrm{~mm}$ YAG rods, followed by two power amplifiers. The beams then pass through potassium dideuterium phosphate $(\mathrm{KD} * \mathrm{P})$ crystals. This nonlinear optical medium serves the purpose of generating the second and fourth harmonics of the fundamental Nd:YAG frequency. The laser has been optimized for the conversion of the fundamental to the fourth harmonic at a wavelength of $266 \mathrm{~nm}$. The initial pump beams are each approximately 9.6 and $9.4 \mathrm{~mm}$ in diameter with a beam divergence of 0.42 and $0.44 \mathrm{mrad}$, respectively. The laser cavities used to pump the Raman cells produce $42 \mathrm{~mJ} \mathrm{pulse}^{-1}$ for the hydrogen cell and $32 \mathrm{~mJ} \mathrm{pulse}^{-1}$ for the deuterium cell.

The two emitted beams are each steered to the Raman cells using two turning mirrors which have been coated to optimize reflectance at $266 \mathrm{~nm}$. The beams pass through converging lenses $(\mathrm{L} 1, \mathrm{~L} 2)$, with focal length $1.0 \mathrm{~m}$, which focus each beam waist near the center of the $1.8 \mathrm{~m}$ long Raman cells. By focusing the beam waist near the center of the Raman cell, the optical interaction volume is maximized, which will give the highest possible conversion of pump photons into first Stokes shift photons (McDermid et al., 2002).

Both ends of the Raman cells are sealed with sapphire optical windows $1.2 \mathrm{~cm}$ thick and $3.8 \mathrm{~cm}$ in diameter; the flanges used to hold these optics allow for a final optical aperture of 
$2.2 \mathrm{~cm}$. Sapphire was chosen in preference over fused silica as the window optical material because it is more thermally and mechanically durable under conditions of continuous laser illumination. After the beams exit the Raman cell, they are collimated with a $1.0 \mathrm{~m}$ re-collimating lens $(\mathrm{L} 3, \mathrm{~L} 4)$ to minimize beam divergence. The beams are then steered and transmitted through the hatch $(90 \mathrm{~cm} \times 92 \mathrm{~cm})$ of the trailer and into the atmosphere.

The GSFC TROPOZ DIAL has a large $45 \mathrm{~cm}$ diameter Newtonian telescope for detecting $289 / 299 \mathrm{~nm}$ at higher altitudes (High) in the free troposphere and four smaller $2.5 \mathrm{~cm}$ telescopes to obtain signal near the surface (Middle, Low) for $289 / 299 \mathrm{~nm}$ (McGee et al., 2005). For the $45 \mathrm{~cm}$ telescope, the lidar return is focused at the field stop with a $1.0 \mathrm{mrad}$ aperture, which defines the field of view (FOV) of the telescope. The $2.5 \mathrm{~cm}$ telescopes have a much wider FOV, $4.5 \mathrm{mrad}$, which causes an increase in the dynamic range of the signals reaching the detector (by allowing the very large signals from the near field into the receiver in addition to the existing weaker signals from the far field). There are very narrow band $(<1.0 \mathrm{~nm}$ FWHM (full width at half maximum)) interference filters (IFs) in front of all of the detectors to decrease the ambient solar background radiation, which improves the SNR. These filters are critical to the system because they are spectrally narrow enough for signal detection during the daytime, when tropospheric ozone is most active. After the backscattered light passes through the interference filters, it is detected by photomultiplier tubes (PMTs). Neutral density filters are used to avoid saturation of the PMTs. Electronic gates are also used on the PMTs to avoid saturation. Having multiple receivers and narrowband interference filters has allowed the TROPOZ to achieve the novel ability, within the United States, of profiling ozone above the tropopause, even during daylight hours.

Individual photons are counted by a transient recorder (LICEL TR 20-80, Licel GmbH, Germany) at a maximum counting rate of $300 \mathrm{MHz}$. This process is controlled by LabView software which was originally developed for use in other NASA lidar instruments and modified to fit the needs of the GSFC TROPOZ DIAL. All of the important specifications for hardware for each altitude and wavelength channel are listed in Table 1.

The large $45 \mathrm{~cm}$ telescope is mounted so that its axis of direction is fixed and can be re-directed only by raising and lowering the hydraulic legs of the trailer. The small $2.5 \mathrm{~cm}$ telescopes, however, are set in adjustable mounts so that they can each be directed independently. The alignment of the system is accomplished by steering the outgoing beams into the region of the $45 \mathrm{~cm}$ telescope's FOV and optimizing the return signals in the channels associated with this telescope. Optimizing these signals entails maximizing the signal level in the far field. After this alignment is achieved, the axial directions of each of the four smaller telescopes are adjusted so that the return signals associated with them are optimized in the same manner as described for the large telescope. This process has been done during cloud-free nighttime hours to minimize solar background and potential contamination of clouds and interfering gases. Geometrically, the $45 \mathrm{~cm}$ telescope should be fully overlapped at $462 \mathrm{~m}$ a.g.l., and the $2.5 \mathrm{~cm}$ telescopes should be fully overlapped at $105 \mathrm{~m}$ a.g.l.

\section{Data processing and algorithm}

The data acquisition system in the GSFC TROPOZ DIAL collects $20 \mathrm{~s}$ (1000 laser shots) integrations of the detected backscattered light. This is a low enough temporal resolution to make the assumption of a homogeneous atmosphere during the time of each individual profile. These $20 \mathrm{~s}$ integrated profiles will be referred to as the raw signal in this paper.

Due to the dynamic variability of ozone concentrations within the PBL and lower free troposphere, it may be necessary to resolve fine-scale mixing features or a layer of ozone aloft at an upper altitude. The temporal resolution is selected depending on the research application and how quickly an ozone episode may be evolving. For example, a 10 min temporal resolution corresponds to the running average of 30 raw signal data sets. The time-averaged data are then background-subtracted using altitudes where the change in slope is negligible, in order to assume a constant background correction. For the data presented in this paper, the background region used is from 30 to $45 \mathrm{~km}$.

After these corrections, it may be necessary to manually remove data sets if they are believed to be contaminated by clouds, which is typically quantified by a large rise in luminosity counts at specific altitudes in the individual detectors. If the cloud optical thickness is fairly low and multiple data sets are averaged together, information may be available above the cloud layer.

The retrieval algorithm must also correct for the nonparalyzable dead-time correction of the photomultiplier tubes (Donovan et al., 1993; Keckhut et al., 2004), which has been empirically determined to be between 4 and $7 \mathrm{~ns}$ for most lidar return signals. These values are quantified by comparing the lidar return signal to a model atmosphere from a standard model or colocated sonde data in the Low channels. Subsequent lidar returns from the Middle and High channels are then corrected to match the overlapping regions of the Low signal returns. This correction can be written as

$C_{\mathrm{t}}=\frac{C_{\mathrm{m}}}{1-C_{\mathrm{m}} T_{\mathrm{d}}}$,

where the true photon count rate $\left(C_{\mathrm{t}}\right)$ can be expressed as a function of the measured count rates $\left(C_{\mathrm{m}}\right)$ and a dead-time $\left(T_{\mathrm{d}}\right)$ parameter (Lampton and Bixler, 1985). This correction is critical in the Low channels, where the PMT signals cover a large dynamic range and the derivative in the DIAL equation is large. Signal-induced bias (SIB) is also quantified, but the channel merge altitudes are selected in a way such that SIB is not a major correction. 
Table 1. Hardware description for the GSFC TROPOZ DIAL system for the transmitter, receiver components, and the data acquisition system.

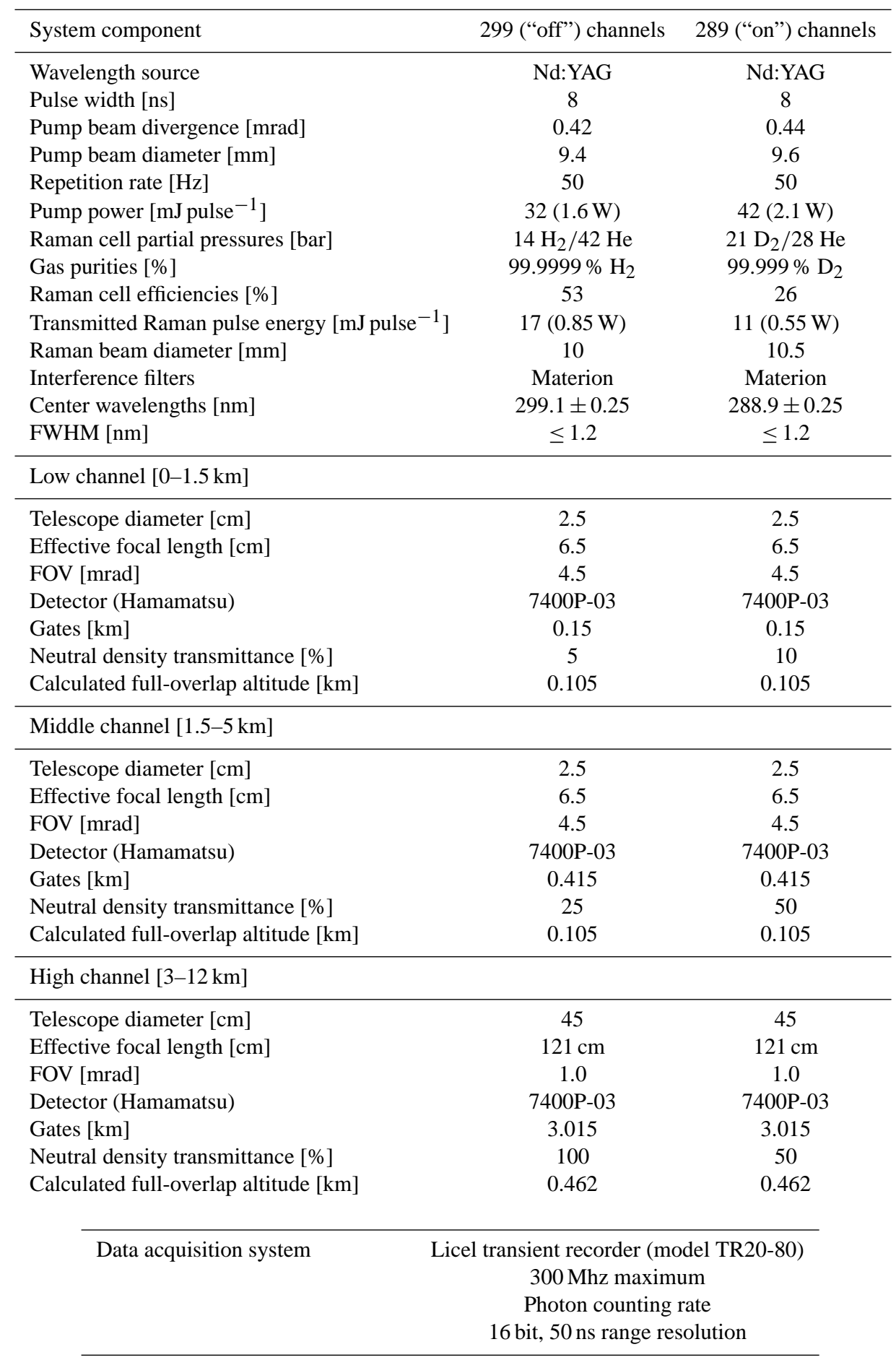

Referring to Eq. (2), the retrieval relies on the derivative of the natural logarithm of the ratio of backscattered laser powers. The finite impulse response (FIR) Savitzky-Golay (SG) differentiation filter has been used to produce the required first-order derivative. The SG filter
(Savitzky and Golay, 1964) is a generalized running average with filter coefficients determined by an unweighted linear least-squares regression and a second-order polynomial model applied to the derivative. The second order was chosen instead of a third or fourth order because it was less likely 
to pick up extreme noise in the derivative. The final vertical resolution of the data is determined using the FWHM of the steady-state SG filter coefficients associated with the filter window size.

Due to a known temperature dependence of the ozone absorption cross sections (Fig. 1, Malicet et al., 1995), it is necessary to get an accurate atmospheric temperature profile, either from a colocated sonde launch or from a standard model atmosphere. Because the ozone absorption temperature dependence is not known continuously, a second-order polynomial interpolation is utilized. The Rayleigh molecular extinction coefficients are also corrected for atmospheric number density values provided by or derived from a colocated sonde launch or from a standard model. After these corrections are made, the first estimate of the ozone profile, $N_{\mathrm{O}_{3}}(r)_{1}$, is computed.

It is necessary to correct the computed ozone profile in instances of a more polluted environment, which may be particularly prevalent within the PBL. Although the data set presented here and analyzed in further sections of this paper is not heavily influenced by aerosol concentrations aloft due to regional and seasonal trends in aerosols, it is important to quantify the aerosol correction in instances of a less polluted environment.

The aerosol extinction term in Eq. (4) depends not only on the wavelength of the interacting photons but also on the aerosol size and type. To quantify this, an iterative algorithm has been used to determine the aerosol backscatter coefficient, which, when coupled with an assumed lidar ratio, will yield an estimate of the aerosol extinction coefficient. The lidar ratio, $S$, is the extinction-to-backscatter ratio,

$S=\alpha(r) / \beta(r)$.

This procedure - which utilizes the offline, less absorbing wavelength of $299 \mathrm{~nm}$ - begins with an initial estimate of the aerosol volume backscatter at a reference height $\left(h_{\text {ref }}\right)$ and constant lidar ratio, which are adapted from Browell et al. (1985) and Kuang et al. (2011).

Rearranging the final DIAL Eq. (2) with the aerosol correction term, it is possible to solve for the first estimate of the volume backscatter coefficient due to aerosol as

$$
\begin{aligned}
\beta_{\text {aer }}(r)_{1}= & \exp (A+B) \\
& \times \frac{r^{2}\left(\beta_{\mathrm{mol}}(r)+\beta_{\mathrm{aer}}\left(h_{\mathrm{ref}}\right)\right)}{(r+\Delta r)^{2}}-\beta_{\mathrm{mol}}(r),
\end{aligned}
$$

where

$A=\ln \left(\frac{P_{299}(r+\Delta r)}{P_{299}(r)}\right)$

and

$B_{i}=-2 N_{\mathrm{O}_{3}}(r)_{i} \sigma_{\mathrm{O}_{3}} \Delta r-2 \Delta r\left(\alpha_{\mathrm{mol}}(r)-S \beta_{\mathrm{aer}}\left(h_{\mathrm{ref}}\right)\right)$.

The previously obtained non-aerosol-corrected ozone number density, $N_{\mathrm{O}_{3}}(r)_{1}$, is used for the first guess of the ozone profile in order to calculate $B_{1}$. The remaining molecular components are calculated from a standard model atmosphere or from a recent sonde launch. The aerosol backscatter coefficient at the reference height ( $h_{\text {ref }}$ is $12 \mathrm{~km}$ ) that is used is $\beta_{\text {aer }}\left(h_{\text {ref }}\right)=1.67 \times 10^{-4} \mathrm{~m}^{-1} \mathrm{sr}^{-1}$, and the lidar ratio is assumed to be $S=60 \mathrm{sr}$ (Sawamura et al., 2014). This inversion technique can be sensitive to the direction of iteration, and, in order to obtain a stable solution, the iterations begin at the reference height and continue towards lower altitudes. At this point, Eq. (7) has been solved for the first complete profile of the aerosol backscatter coefficient, $\beta_{\text {aer }}(r)_{1}$.

For the second iteration, a more accurate value of the aerosol backscatter coefficient can be computed by making the substitution of

$$
S \beta_{\text {aer }}\left(h_{\text {ref }}\right)=S\left(\beta_{\text {aer }}(r)_{1}+\beta_{\text {aer }}(r+\Delta r)_{1}\right) / 2 .
$$

This can be solved for the new aerosol backscatter coefficient, $\beta_{\text {aer }}(r)_{2}$.

This iterative process continues, making the necessary substitution of

$\beta_{\text {aer }}(r)_{i+1}+\beta_{\text {aer }}(r+\Delta r)_{i+1}=\beta_{\text {aer }}(r)_{i}+\beta_{\text {aer }}(r+\Delta r)_{i}$,

until a stable solution is reached, where the difference in iterations of the profile is negligible. The final aerosol backscatter term is then inserted into the full DIAL Eqs. (3) and (4) for the final corrected ozone mixing ratio profile. In previous literature, in the presence of large aerosol concentrations, this correction may be on the order of $25 \%$ (Browell et al., 1985; Papayannis et al., 1990). In the test case presented below, which showed very little aerosol influence aloft, the calculated corrections in the final reported ozone mixing ratios were $<3 \mathrm{ppbv}(12 \%)$ in the Low channels and $<1 \mathrm{ppbv}$ $(2 \%)$ in the Middle and High channels.

The final aerosol-corrected ozone profile is then joined to form one continuous hybrid profile. The profile join regions are chosen to maximize SNR, which is at its highest in the lower range of each profile and significantly deteriorates at the top range of each profile. With the current configuration for a $10 \mathrm{~min}$ temporal running average and a fixed SG filter window size, the vertical resolution of the Low channels is $275 \mathrm{~m}$, the Middle channels is $525 \mathrm{~m}$, and the High channels is $750 \mathrm{~m}$.

\section{Comparison with Beltsville, MD ozonesonde (25 October 2013)}

As mentioned before, the mid-Atlantic region displays a moderate amount of seasonal ozone variability, with the highest concentrations occurring in the late July time period (Lehman et al., 2004). Because of this, during the fall and winter seasons, the TROPOZ focuses its observations on monitoring ozone in the free troposphere and the aforementioned source contributions, such as STE. While taking measurements on 25 October 2013, an unusually low tropopause 
was observed, resulting in the exchange of high amounts of ozone between the stratosphere and the lower free troposphere. An ozonesonde was launched that day by the Howard University Beltsville Center for Climate Systems Observation, which serves as the validation source for the TROPOZ ozone profiles. The launch site $\left(39.05^{\circ} \mathrm{N}, 76.88^{\circ} \mathrm{W}\right)$ is approximately $8 \mathrm{~km}$ from the lidar site which is close enough to assume similar, but not identical, tropospheric micrometeorology in the dynamic daytime PBL.

A $10 \mathrm{~min}$ retrieved lidar ozone profile from 17:54 UTC (averaged from 17:49 to 17:59 UTC) together with the ozonesonde profile (17:44 UTC launch) are shown in Fig. 5. These times were chosen for the comparison to maximize overlap of the two instruments based on the sonde's proximity to the lidar and ascent rate. The full retrieved range of the lidar profile (red) is from $400 \mathrm{~m}$ to $12 \mathrm{~km}$ a.g.l., in which three channels are used. The green and gold profiles indicate the unused signal from a higher adjoining channel with better SNR to a lower region. Having multiple channels is advantageous for retrieving a continuous high temporal resolution profile with a large dynamic scattering range from the atmosphere.

The ozonesonde (dark blue) shows a PBL height near $1.5 \mathrm{~km}$, which is based on the slight ozone mixing ratio gradient $(<5 \mathrm{ppbv})$, which is typical for the Mid Atlantic region during this season. Above the PBL, both profiles have values in the range 30-40 ppbv until the strong ozone gradient near $6.5 \mathrm{~km}$. Both the sonde and the lidar capture this strong ozone reservoir, where the difference in the altitude of the reservoir may be attributed to the distance between sites based on the fact that the ozonesonde profile still resides within the uncertainty of the retrieved profile. The bias between the TROPOZ and the ozonesonde is $\pm 20 \%$ throughout most of the atmosphere except for the large oscillation in the ozonesonde profile at $8.75 \mathrm{~km}$ that the lidar was not able to resolve completely and for which a bias of nearly $30 \%$ occurs. This anomalous ozone reservoir, which was around 150-200 ppbv, had a higher ozone mixing ratio than most summer days, and previous test cases did not reach these values until $12 \mathrm{~km}$, which emphasizes the regional and seasonal uniqueness of this test case. The uncertainty bars shown in the retrieved TROPOZ ozone profile are dominated by the statistical uncertainty of photon counting and SNR, which are discussed more in Sect. 6.

The TROPOZ profile differs from the sonde profile above $8 \mathrm{~km}$; a partial explanation for this can be seen in Fig. 6 . This image shows the GPS trajectory of the sonde for its first $10 \mathrm{~km}$ of ascent overlain on a map of the area. The black triangle denotes the TROPOZ site, the red triangle denotes the sonde launch site, and the colors of the trajectory track represent the altitude of the sonde. The sonde was launched at Beltsville, MD and was closest to GSFC in the ascent at an altitude near $3 \mathrm{~km}$, which also implies that the difference in ozone mixing ratio in the first $2 \mathrm{~km}$ may be due to the distance between sites. As the sonde continued along this

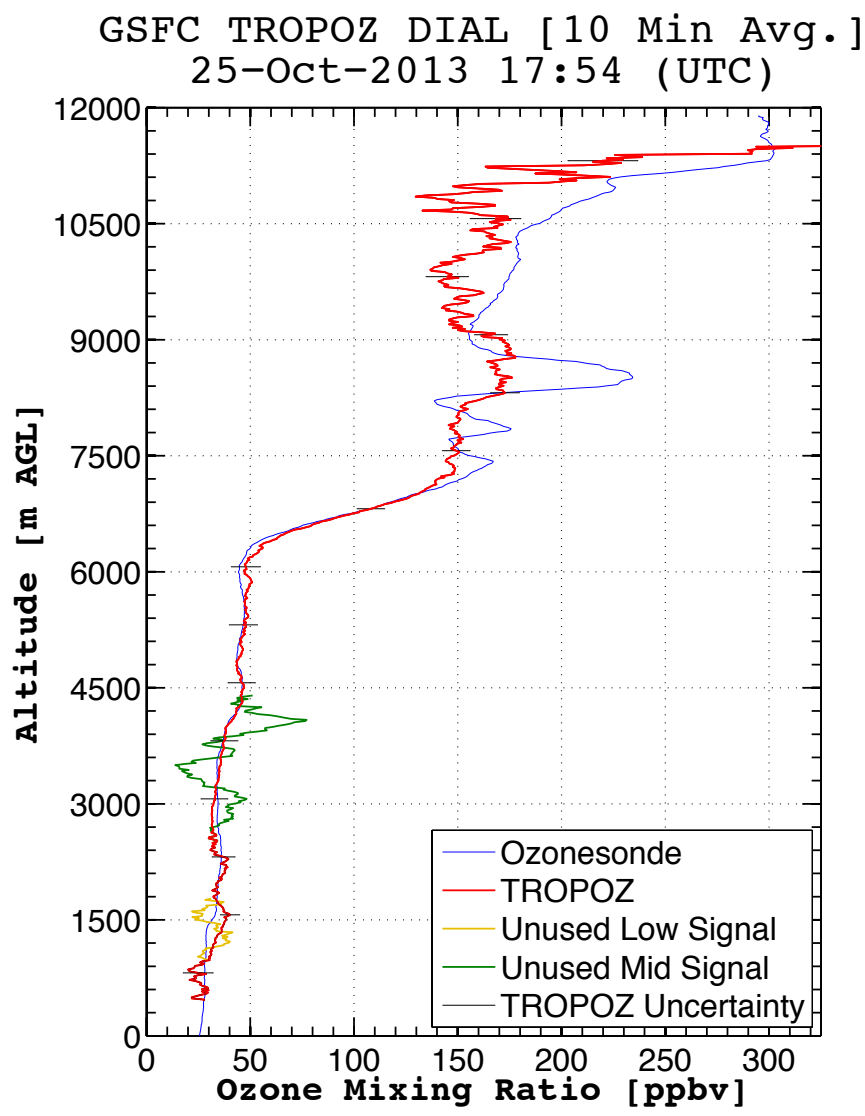

Figure 5. The profile comparison for the GSFC TROPOZ DIAL retrieval (10 min resolution) and the ozonesonde launch at 17:54 UTC on 25 October 2013 at Beltsville, MD. (Source: Howard University Beltsville Center for Climate Systems Observation)

trajectory, it entered a marine environment. The eastern end of the trajectory, where the sonde had achieved $10 \mathrm{~km}$ altitude, is near Edgewater, MD, nearly $30 \mathrm{~km}$ away from the lidar site. Because the lidar is in an Eulerian frame of reference in the inland urban environment, it was not actually resolving the same air mass that is present at the beginning or end of the Lagrangian frame of reference of the sonde. This highlights one of the inherent complications in using ozonesondes as a validation source for lidar. Because the lidar is stationary, the resolved ozone profiles are more representative of the ozone profile at the observation site.

The ozone mixing ratio, relative humidity, and temperature are plotted from the ECC and radiosonde in Fig. 7. The sonde resolves a PBL height near $1.5 \mathrm{~km}$, which is based on the slight ozone mixing ratio gradient $(<5 \mathrm{ppb})$, the strong relative humidity gradient $(40 \%)$, and the temperature inversion $(3 \mathrm{~K})$. Besides the PBL gradient, the ozone mixing ratio is fairly constant in the first $6 \mathrm{~km}$ with low variability until the large ozone gradient at $6.5 \mathrm{~km}$. Above that point there are large oscillations that imply a dynamic system of ozone in this region. The relative humidity profile shows a strong 


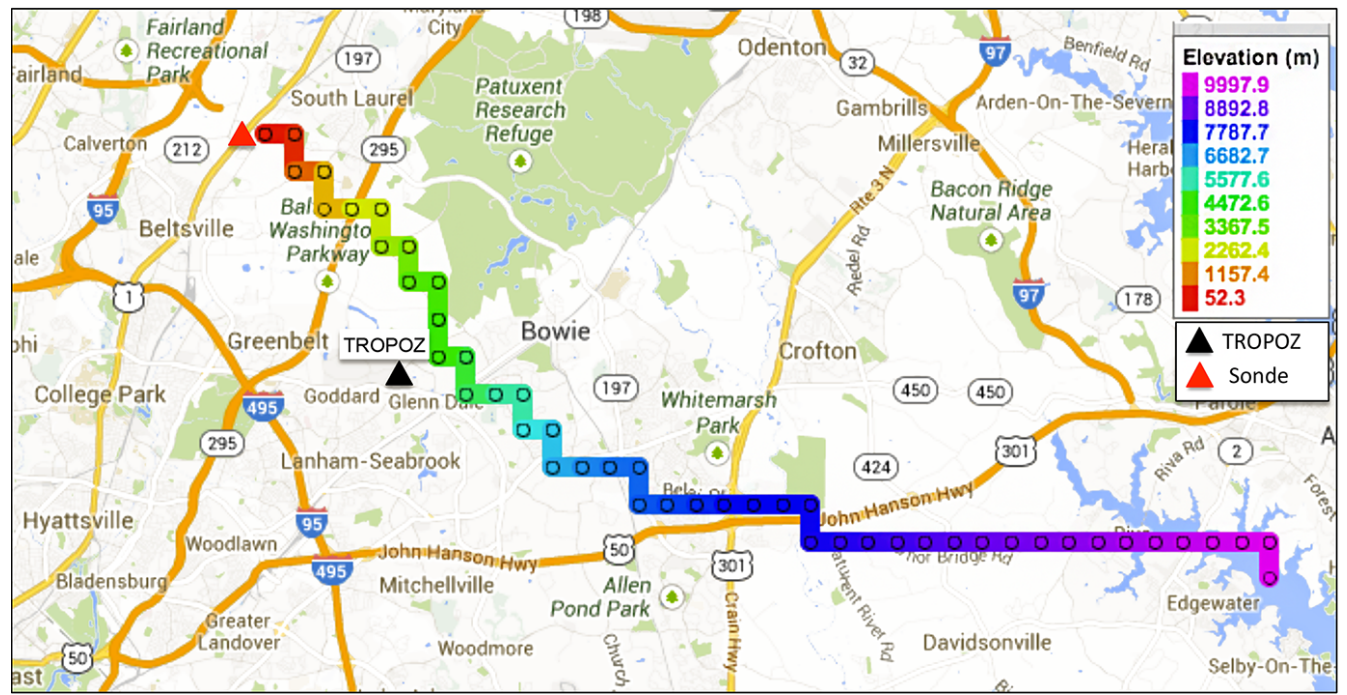

Figure 6. Ozonesonde GPS coordinates during the ozonesonde flight. The black triangle shows the location of the TROPOZ; the red triangle shows the location of the sonde launch site in Beltsville, MD; and the varying colors represent the altitude and trajectory of the sonde. When the sonde is above $7 \mathrm{~km}$ (light and dark blue), it is $16 \mathrm{~km}$ away from the lidar; at a altitude of $10 \mathrm{~km}$ (magenta) it is near $30 \mathrm{~km}$ away from the lidar. The altitude legend is on the right side of the figure. (Source: Howard University Beltsville Center for Climate Systems Observation; map source: Google Maps.)

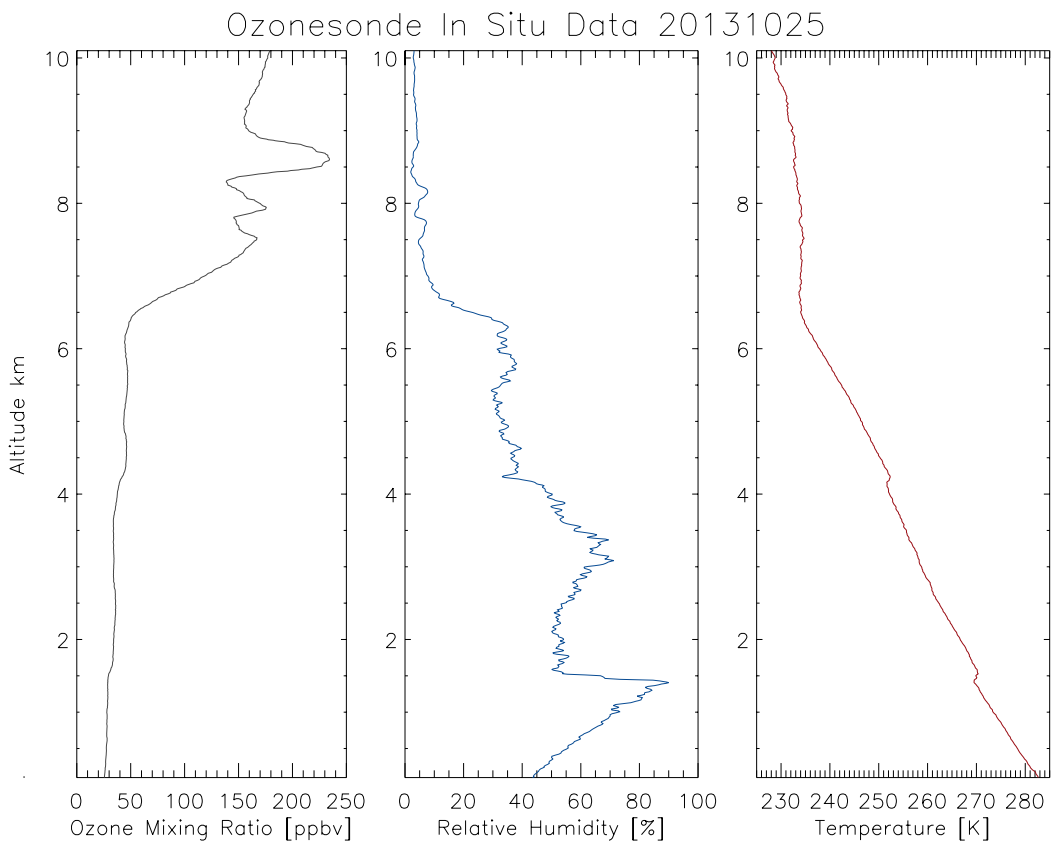

Figure 7. The radiosonde and ECC in situ data for ozone mixing ratio, relative humidity, and temperature plotted for the test case on 25 October 2013. (Source: Howard University Beltsville Center for Climate Systems Observation.)

gradient at the top of the PBL, but above that the air slowly gets drier until about $6.5 \mathrm{~km}$, where it also undergoes a strong gradient. The relative humidity also shows some small oscillations that correspond to the same altitudes as the dynamic ozone oscillations. The temperature profile exhibits a linear decrease up to $6.5 \mathrm{~km}$, above which the temperature remains nearly constant for $2 \mathrm{~km}$. This, together with the observation of a dry air mass above $6.5 \mathrm{~km}$, indicates an unusually low tropopause height near $6.5 \mathrm{~km}$. This implies that this air mass is most likely of stratospheric origin and can be considered an ozone intrusion event and can be classified as STE (Reiter, 1975). 


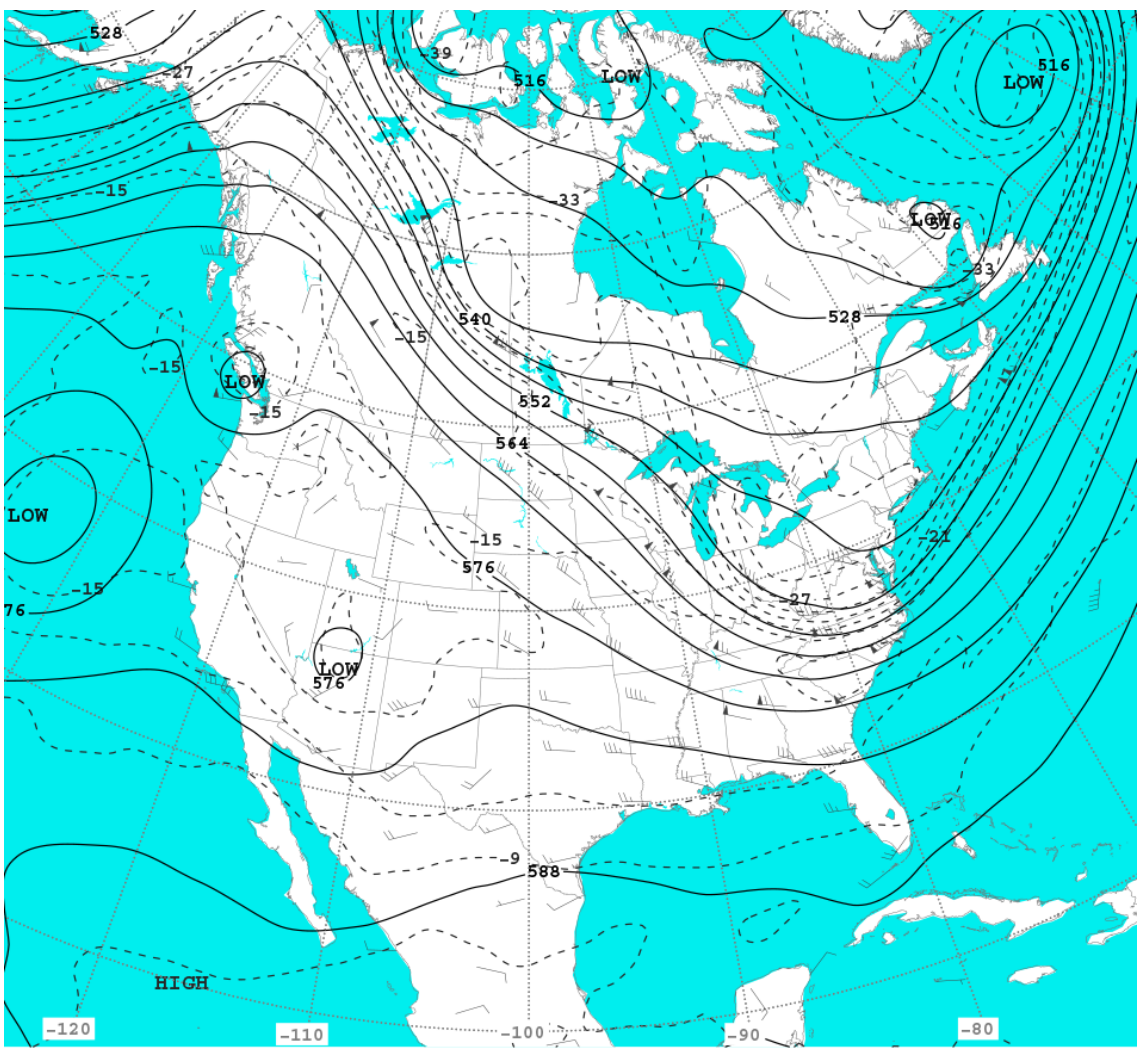

Figure 8. A 500 millibar (mb) height contour national map for 11:00 UTC on 25 October 2013, for the meteorological events that surrounded the test case is shown. The figure shows height contours (solid lines), temperatures (dashed lines), and winds (arrows). The height contours show the height of the $500 \mathrm{mb}$ pressure level in dekameters above sea level; the isotherms, or lines of constant temperature, are shown in degrees Celsius; and the arrows show the wind direction and speed at the $500 \mathrm{mb}$ level. (Source: NOAA Daily Weather Map.)

A 500-millibar $(\mathrm{mb})$ height contour national map for 11:00 UTC on 25 October 2013, courtesy of NOAA Daily Weather Map, for the meteorological events that surrounded the test case is shown in Fig. 8. The chart shows height contours (solid lines), temperatures (dashed lines), and winds (arrows). The height contours show the height of the $500 \mathrm{mb}$ pressure level in dekameters above sea level; the isotherms, or lines of constant temperature, are shown in degrees Celsius; and the arrows show the wind direction and speed at the $500 \mathrm{mb}$ level. The map shows a persistent low-pressure system occurring in the mid-Atlantic and Ohio River Valley regions just underneath the tropopause height around $6.5 \mathrm{~km}$. This disturbance is exemplified by the deviation from the trough of closely spaced geopotential height contours (solid black lines) and in the temperature contours (dashed black lines). Also, notice the strong increase in northwesterly winds associated with the steep pressure gradients that have occurred just below the tropopause around $6.5 \mathrm{~km}$. This wind pattern is most likely the polar jet stream (Viezee et al., 1983), which is typically stronger in winter and fall months and was the reason why the ozonesonde in Fig. 6 moved so quickly in the zonal direction away from the launch site as it got nearer to the tropopause height. The low-pressure system was present in national maps as early as 23:00 UTC on 24 October 2013 and slowly subsided and evolved throughout 25 October 2013 as can be seen in the lidar curtain plots in Fig. 9a and $b$.

Figure 9a shows the time series from 15:19 to 22:18 UTC (11:19-18:18 EDT) with the overlaid ozonesonde data corresponding to the red arrow point at 17:44 UTC. This image is created from a 10 min running average of the data with all altitude channels merged together to form a complete profile of the atmosphere from $400 \mathrm{~m}$ to $12 \mathrm{~km}$. It is possible to see the strong gradient in ozone near $7 \mathrm{~km}$ and large ozone concentrations that dissipate mainly through titration during the afternoon and early evening. The upper level cold and dry air pockets behind the persistent low-pressure system inject a large ozone reservoir (150-200 ppbv) into the free troposphere, effectively lowering and maintaining a tropopause height near $6.5 \mathrm{~km}$. The in situ surface ozone mixing ratios from the GSFC TROPOZ DIAL trailer (Thermo Scientific $49 \mathrm{i}, 1 \mathrm{~min}$ resolution) are reported in the first bin in the time series below the retrievable altitude. These values range from 18 to $24 \mathrm{ppbv}$ at the surface for the entire experiment, which implies at ground level the ozone was behaving like a typical early winter mid-Atlantic regional atmosphere. Based on the 


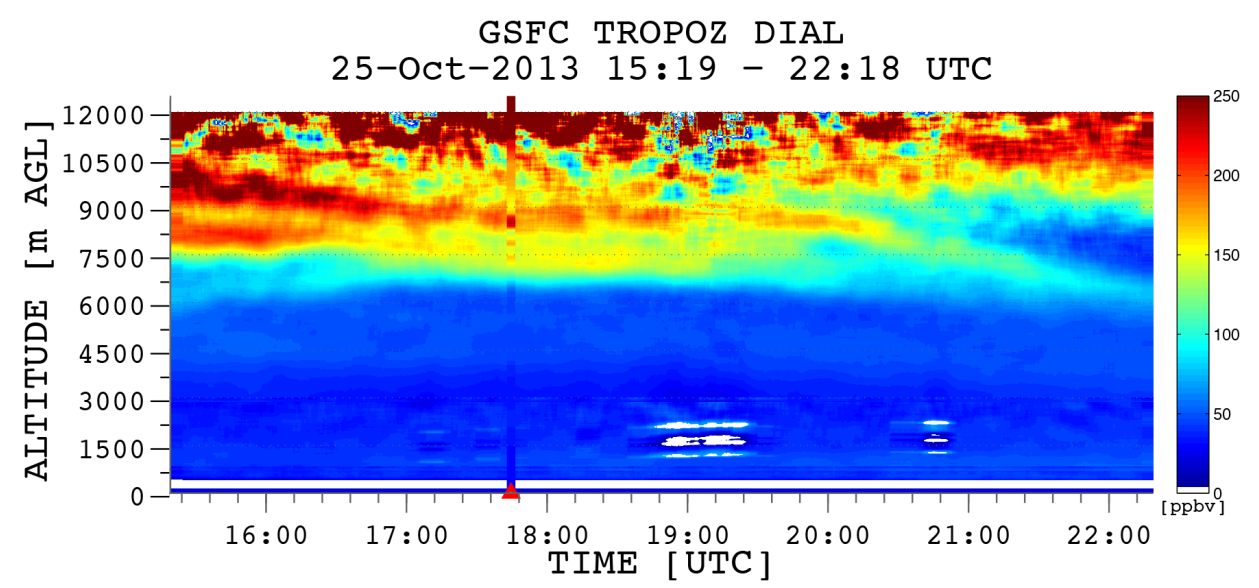

Figure 9a. Time series plot of the ozone mixing ratio [ppbv] from the GSFC TROPOZ DIAL between 15:19 and 22:18 UTC (11:1918:18 EDT) at a $10 \mathrm{~min}$ temporal resolution, with the colocated ozonesonde launch corresponding to the red arrow point at 17:44 UTC. The surface ozone monitor mixing ratios ( 1 min resolution) are plotted in the lowest bin of the figure.

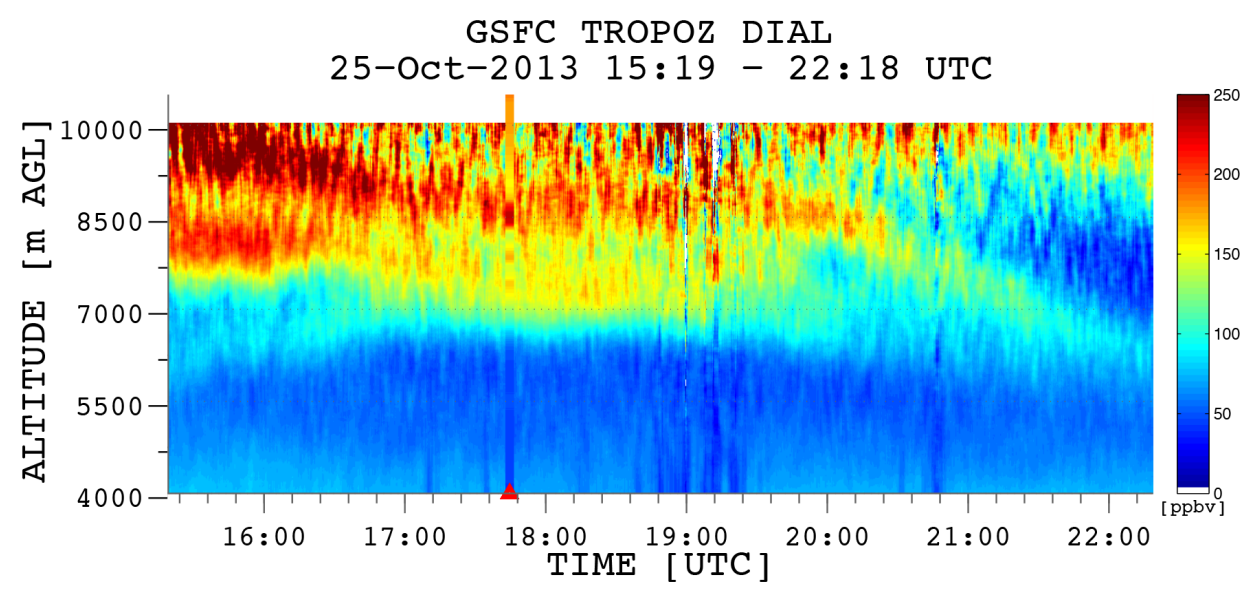

Figure 9b. Time series plot of the ozone mixing ratio [ppbv] from the GSFC TROPOZ DIAL between 15:19 and 22:18 UTC (11:1918:18 EDT) at a 1 min temporal resolution, with the colocated ozonesonde launch corresponding to the red arrow point at 17:44 UTC. This plot focuses attention on the upper atmospheric conditions in order to represent the ability to monitor the changing dynamics of the ozone reservoir on a very short timescale.

northwest direction and strong wind speeds shown in Fig. 8, there was dilution and ventilation of ozone precursors, which resulted in a low amount of ozone near the surface from local pollution.

Around 19:00 and 21:00 UTC, thin clouds drifted through the field of view during the observation, the effects of which can be seen as white space in the figure. Because the $10 \mathrm{~min}$ observation is a running average over 30 profiles, and because the clouds were thin and did not form broad cover, retrieval information can be seen above the clouds in the curtain plot.

The curtain plot in Fig. 9b shows the same data set with a temporal resolution of $1 \mathrm{~min}$ from 4 to $10 \mathrm{~km}$. This is a high enough resolution to begin to pick out some of the smallscale features in the ozone curtain plot. With a running average of just three profiles, retrieval above the clouds is lost - hence the vertical white lines that appear in Fig. 9b. Averaging fewer profiles increases the uncertainty in the measurement, and the retrieved ozone profile at 1 min resolution can only reach $10 \mathrm{~km}$ (as opposed to $12 \mathrm{~km}$ with a $10 \mathrm{~min}$ resolution) before the SNR is too small to yield useful information.

This plot focuses attention on the upper atmospheric conditions in order to represent the ability to monitor the changing dynamics of the ozone reservoir on a very short timescale. It is possible to see small pockets of clean air, which implies that there was some dynamic mixing of clean tropospheric air and high-ozone stratospheric air. There is also an interesting wavelike feature in the ozone concentration towards the end of the run (20:30-22:18 at $6.5 \mathrm{~km})$ that may have been the cause for the ozone reservoir to split and begin to both subside towards the surface and to rise back to the upper free troposphere. The ozone-free region between 
Table 2. A list of the quantified uncertainties associated with the GSFC TROPOZ DIAL instrument during the test case on 25 October 2013.

\begin{tabular}{lrrr}
\hline & $\begin{array}{r}\text { Low channel } \\
{[0-1.5 \mathrm{~km}]}\end{array}$ & $\begin{array}{r}\text { Middle channel } \\
{[1.5-5 \mathrm{~km}]}\end{array}$ & $\begin{array}{r}\text { High channel } \\
{[3-12 \mathrm{~km}]}\end{array}$ \\
\hline Statistical uncertainty & $1-10 \%$ & $1-16 \%$ & $1-24 \%$ \\
Aerosol correction & $<12 \%$ & $<4 \%$ & $<4 \%$ \\
Rayleigh correction & $<1 \%$ & $<1 \%$ & $<1 \%$ \\
$\mathrm{SO}_{2}$ & $-1 \%$ & $-1 \%$ & $-1 \%$ \\
$\mathrm{NO}_{2}$ & $-0.5 \%$ & $-0.5 \%$ & $-0.5 \%$ \\
$\mathrm{O}_{2}-$ dimer & $1.5 \%$ & $1.5 \%$ & $1.5 \%$ \\
Temperature dependence of $\Delta \sigma_{\mathrm{O}_{3}}$ & $3 \%$ & $3 \%$ & $3 \%$ \\
Saturation correction & $10 \%$ & $5 \%$ & $3 \%$ \\
\hline Final reported & $16-19 \%$ & $10-18 \%$ & $11-25 \%$ \\
\hline
\end{tabular}

two ozone enhanced layers is certainly characteristic of a tropopause fold event (Viezee et al., 1983), but without the meteorological parameters from a radiosonde it is difficult to confirm the fold. Dilution of this ozone may have occurred in the atmosphere during the times at which the TROPOZ was not taking measurements, especially with high winds pushing the air mass out towards the Chesapeake Bay.

Surface monitors did show an increase in ozone on 26 October 2013; but, with the passing front bringing warm, sunny weather, it is challenging to determine whether the surface ozone source was due to the dynamic STE or created by photochemistry within the PBL.

Due to the unusually high amount of ozone in the atmosphere during this test case, the usable return signal was absorbed much more strongly than on a typical day. Because of this, ozone mixing ratios are only reported to $12 \mathrm{~km}$. For conditions of nighttime observations and longer temporal averages, ozone retrievals can be attained at a higher altitude. Although this plot emphasizes the upper atmospheric conditions for this regionally important test case, it provides evidence that the GSFC TROPOZ DIAL will be able to provide high-resolution ozone observations within the dynamic PBL.

\section{Accuracy of the DIAL measurement}

The GSFC TROPOZ DIAL system detects individual photons through the use of photomultiplier tubes. The signal collected by these PMTs follows Poisson statistics (Megie et al., 1985; Papayannis et al., 1990), and the statistical uncertainty of the ozone number density can be calculated as

$\epsilon_{N_{\mathrm{O}_{3}}}(r, \lambda)=\frac{1}{2 N_{\mathrm{O}_{3}} \Delta \sigma_{\mathrm{O}_{3}} \Delta r} \sqrt{\frac{P_{\mathrm{s}, \lambda}+P_{\mathrm{b}, \lambda}+P_{\mathrm{d}, \lambda}}{P_{\mathrm{s}, \lambda}^{2}}}$,

where $P_{\mathrm{s}, \lambda}, P_{\mathrm{b}, \lambda}$, and $P_{\mathrm{d}, \lambda}$ are respectively the atmospheric backscattered signal, background radiation, and dark counts of the detector at wavelength $\lambda$. The total statistical uncertainty is then calculated from the statistical uncertainty from each DIAL wavelength added in quadrature. The vertical resolution, which is based on the SG filter window size, is denoted as $\Delta r$, and the differential ozone absorption cross section is denoted as $\Delta \sigma_{\mathrm{O}_{3}}$. The statistical uncertainty is related to the square root of the total PMT counts, both those that are relevant to the retrieval of ozone number density and those that are counts due to systematic uncertainties. By integrating profiles for a longer duration, the backscattered signal term $P_{\mathrm{s}, \lambda}$ becomes much larger than the $P_{\mathrm{b}, \lambda}$ and $P_{\mathrm{d}, \lambda}$ terms. For this reason, the temporal resolution is inherently built into the statistical uncertainty of the system, and averaging many data sets is beneficial to the resultant uncertainty in the system.

By increasing the vertical resolution of the profile, which is in the denominator of Eq. (12), the statistical uncertainty in the measurement decreases. Because the vertical resolution changes with the retrieval range and has different values for different channel pairs, the resultant uncertainty profile exhibits changes at the altitudes at which the channels are merged. This can be seen in the uncertainty bars in Fig. 5 .

Aside from the statistical uncertainty, there are uncertainties associated with the spectral dependence of other interfering species, such as aerosols, non-ozone interfering gases, and the Rayleigh atmosphere. There are also uncertainties that are independent of atmospheric conditions and cannot be decreased by averaging multiple profiles together, such as the temperature dependence of the ozone absorption cross section used and the saturation correction.

Table 2 lists the various uncertainties due to individual photon counting, interfering gases, the temperature dependence of the ozone cross section, and the saturation correction for the test case discussed in the previous section. As mentioned in the Data processing portion of this paper, an iterative aerosol correction was applied to this test case, which resulted in a $<3$ ppbv $(<12 \%)$ ozone correction in the Low channels and a $<1 \mathrm{ppbv}(<2 \%)$ correction in the Middle and High channels. Further uncertainties arise from interfering gases that have similar absorption cross sections at the DIAL wavelengths (Keckhut et al., 2004). Based on standard trace gas profiles (Heikes et al., 1987; Lin and McElroy, 
2010) an uncertainty of $1.5 \%$ in overall retrieved ozone has been calculated due to absorption at the DIAL wavelengths by the oxygen dimer $\left(\mathrm{O}_{2}-\mathrm{O}_{2}\right)$ interaction (Fally et al., 2000) and smaller than $-0.5 \%$ uncertainty due to nitrogen dioxide $\left(\mathrm{NO}_{2}\right)$ (Bogumil et al., 2003), as well as a smaller than $-1.0 \%$ uncertainty due to sulfur dioxide $\left(\mathrm{SO}_{2}\right)$ (Stark et al., 1999) unless there is a large pollution event or influence from volcanic emission present (Ancellet et al., 1987; McGee et al., 1993). The largest uncertainties from these gases typically arise within the PBL, and this is the uncertainty reported. The uncertainty in the Rayleigh extinction correction is typically $<1 \%$ due to the dependence on the atmospheric number density, which may be calculated from a standard model atmosphere or recent radiosonde. Similarly, the temperature dependence of the ozone absorption cross sections should contribute less than $3 \%$ to the uncertainty in the final ozone number density (Leblanc et al., 1998). Additionally, the correction for the saturation of the detectors cannot be reduced by additional averaging as it is determined using the maximum counting rate of the data acquisition system $(300 \mathrm{MHz})$. This uncertainty is based on the differences in the saturation-corrected retrieved ozone profile and the uncorrected profiles. This is an altitude-dependent correction, and the largest uncertainties (which are reported) occur near the bottom of each profile.

Other than the uncertainty due to the presence of aerosols, and to a lesser extent those due to Rayleigh extinction and saturation correction, these values in Table 2 can be taken as representative of the uncertainties in ozone retrieval for the GSFC TROPOZ DIAL instrument. The uncertainties are largest in the Low channel due to the presence of aerosols and the complete use of the saturation correction. In the Middle and High channels, there are fewer aerosols present and there is enough overlap between the Low and Middle and between the Middle and High channels to join them at altitudes such that regions where saturation is non-negligible can be excluded from the overall profile. The reported resultant uncertainty, added in quadrature, from 0 to $1.5 \mathrm{~km}$ is $16-19 \%$, $1.5-3 \mathrm{~km}$ is $10-18 \%$, and from 3 to $12 \mathrm{~km}$ is $11-25 \%$.

\section{Conclusions}

The GSFC TROPOZ DIAL has been utilized to detect tropospheric ozone, a very important greenhouse gas for climate and health studies. Due to complex tropospheric chemistry and various free-tropospheric ozone sources, modeling these lower levels of the atmosphere can be extremely difficult, and empirical observations of ozone may be far more useful. The necessary theory and initial optical layout of the GSFC TROPOZ DIAL in order to retrieve and better characterize the vertical distribution of tropospheric ozone in the Baltimore-Washington, D.C. area has been established. A regionally important validation test case of an unusually low tropopause - resulting in the exchange of high amounts of ozone between the stratosphere and the lower free troposphere, or STE - is presented and analyzed.

Measurements of the STE are presented with a temporal resolution of 10 and 1 min with a maximum altitude of $12 \mathrm{~km}$. Because of the optically thick stratospheric ozone layer, a ground-based detection method that can detect tropospheric ozone on a continuous, high-resolution scale is advantageous. The GSFC TROPOZ DIAL system has been shown to be a less expensive and more robust alternative to previous lidar systems with the implementation of Raman cells, which have had no observable drop in pressure since they were initially filled in June 2013. The data processing and aerosol correction algorithms have been introduced and have shown good agreement with a colocated ozonesonde measurement. The reported resultant uncertainty from 0 to $1.5 \mathrm{~km}$ is $16-19 \%, 1.5-3 \mathrm{~km}$ is $10-18 \%$, and from 3 to $12 \mathrm{~km}$ is $11-25 \%$.

Future plans for the GSFC TROPOZ DIAL are to obtain ozone profiles as close to the surface as possible ( $<100 \mathrm{~m}$ a.g.1.), which will require ozonesonde launches directly at the lidar site. As mentioned previously, the Raman cells were filled to a pressure which left a residual amount of $266 \mathrm{~nm}$ for atmospheric transmission. Because this wavelength is strongly absorbed by ozone, it may only be able to yield useful information from the surface to the top of the PBL, but may have enough signal to characterize and probe the dynamic PBL, especially in the urban region. The advantage of adding $266 \mathrm{~nm}$ to this system would be to get a more robust aerosol correction method using a dual-DIAL wavelength retrieval (Papayannis et al., 1990).

Depending on the atmospheric event the TROPOZ is intended to monitor, averaging of the data may be minimized to detect natural variability and small ozone fluctuations or maximized to reach higher altitudes for climatology purposes. The GSFC TROPOZ DIAL is a new and unique tool for the air-quality community in the BaltimoreWashington, D.C. region because it can provide a continuous, high-resolution, and novel perspective of ozone pollution episodes during the daytime from near the surface to the tropopause. For these reasons, the GSFC TROPOZ DIAL is a very valuable instrument for quantifying the vertical distribution of ozone, especially for distinguishing layers of ozone aloft and STE events that surface monitors do not have the ability to detect.

Acknowledgements. The authors wish gratefully to acknowledge support for this study provided from UMBC/JCET (task no. 374, project 8306), the Maryland Department of the Environment (MDE, contract no. U00P4400079), NOAA-CREST CCNY Foundation (sub-contract no. 49173B-02), and the Tropospheric Ozone Lidar Network (TOLNet). Also, thanks to the Howard University Beltsville Center for Climate Systems Observation for launching the ozonesondes necessary to begin validating this system.

Edited by: M. Hamilton 


\section{References}

Alvarez, R. J., Senff, C. J., Langford, A. O., Weickmann, A. M., Law, D. C., Machol, J. L., Merritt, D. A., Marchbanks, R. D., Sandberg, S. P., Brewer, W. A., Hardesty, R. M., and Banta, R. M.: Development and Application of a Compact, Tunable, Solid-State Airborne Ozone Lidar System for Boundary Layer Profiling, J. Atmos. Ocean. Technol., 28, 1258-1272, 2011.

Ancellet, G. and Ravetta, F.: Compact Airborne Lidar for Tropospheric Ozone: Description and Field Measurements, Appl. Opt., 37, 5509-5521, 1998.

Ancellet, G., Megie, G., Pelon, J., Capitini, R., and Renaut, D.: Lidar measurements of sulfur dioxide and ozone in the boundary layer during the 1983 Fos Berre Campaign, Atmos. Environ. (1967), 21, 2215-2226, 1987.

Ancellet, G., Papayannis, A., Pelon, J., and Megie, G.: DIAL tropospheric ozone measurement using a Nd:YAG laser and the Raman shifting technique, J. Atmos. Ocean. Technol., 6, 832-839, 1989.

Banta, R. M., Senff, C. J., Nielsen-Gammon, J., Darby, L. S., Ryerson, T. B., Alvarez, R. J., Sandberg, S. P., Williams, E. J., and Trainer, M.: A Bad Air Day in Houston, Bull. Am. Meteorol. Soc., 86, 657-669, 2005.

Bogumil, K., Orphal, J., Homann, T., Voigt, S., Spietz, P., Fleischmann, O., Vogel, A., Hartmann, M., Kromminga, H., Bovensmann, H., Frerick, J., and Burrows, J.: Measurements of molecular absorption spectra with the SCIAMACHY pre-flight model: instrument characterization and reference data for atmospheric remote-sensing in the $230-2380 \mathrm{~nm}$ region, J. Photochem. Photobiol. A, 157, 167-184, 2003.

Bösenberg, J.: Ground-Based Differential Absorption Lidar for Water-Vapor and Temperature Profiling: Methodology, Appl. Opt., 37, 3845-3860, 1998.

Bowman, K. W., Steck, T., Worden, H. M., Worden, J., Clough, S., and Rodgers, C.: Capturing time and vertical variability of tropospheric ozone: A study using TES nadir retrievals, J. Geophys. Res.-Atmos., 107, ACH 21-1-ACH 21-11, doi:10.1029/2002JD002150, 2002.

Boynard, A., Clerbaux, C., Coheur, P.-F., Hurtmans, D., Turquety, S., George, M., Hadji-Lazaro, J., Keim, C., and MeyerArnek, J.: Measurements of total and tropospheric ozone from IASI: comparison with correlative satellite, ground-based and ozonesonde observations, Atmos. Chem. Phys., 9, 6255-6271, doi:10.5194/acp-9-6255-2009, 2009.

Browell, E.: Remote Sensing of Tropospheric Gases and Aerosols with an Airborne DIAL System, in: Optical and Laser Remote Sensing, edited by Killinger, D. and Mooradian, A., vol. 39 of Springer Series in Optical Sciences, 138-147, doi:10.1007/9783-540-39552-2_18, 1983.

Browell, E.: Differential absorption lidar sensing of ozone, Proc. IEEE, 77, 419-432, 1989.

Browell, E. V., Wilkerson, T. D., and Mcilrath, T. J.: Water vapor differential absorption lidar development and evaluation, Appl. Opt., 18, 3474-3483, 1979.

Browell, E. V., Carter, A. F., Shipley, S. T., Allen, R. J., Butler, C. F., Mayo, M. N., Jr, J. H. S., and Hall, W. M.: NASA multipurpose airborne DIAL system and measurements of ozone and aerosol profiles, Appl. Opt., 22, 522-534, 1983.
Browell, E. V., Ismail, S., and Shipley, S. T.: Ultraviolet DIAL measurements of $\mathrm{O} 3$ profiles in regions of spatially inhomogeneous aerosols, Appl. Opt., 24, 2827-2836, 1985.

Browell, E. V., Danielsen, E. F., Ismail, S., Gregory, G. L., and Beck, S. M.: Tropopause fold structure determined from airborne lidar and in situ measurements, J. Geophys. Res.-Atmos., 92, 2112-2120, doi:10.1029/JD092iD02p02112, 1987.

Browell, E. V., Butler, C. F., Fenn, M. A., Grant, W. B., Ismail, S., Schoeberl, M. R., Toon, O. B., Loewenstein, M., and Podolske, J. R.: Ozone and Aerosol Changes During the 1991-1992 Airborne Arctic Stratospheric Expedition, Science, 261, 1155-1158, 1993.

Carlsten, J. L., Telle, J. M., and Wenzel, R. G.: Efficient stimulated Raman scattering due to absence of second Stokes growth, Opt. Lett., 9, 353-355, 1984.

Delgado, R., Rabenhorst, S., Demoz, B., and Hoff, R.: Elastic lidar measurements of summer nocturnal low level jet events over Baltimore, Maryland, J. Atmos. Chem., Jan 2014, 1-23, doi:10.1007/s10874-013-9277-2, 2014.

Demerjian, K. L.: A review of national monitoring networks in North America, Atmospheric Environment, 34, 1861-1884, 2000.

de Schoulepnikoff, L., Mitev, V., Simeonov, V., Calpini, B., and van den Bergh, H.: Experimental investigation of high-power single-pass Raman shifters in the ultraviolet with Nd:YAG and KrF lasers, Appl. Opt., 36, 5026-5043, 1997.

Dion, P. and May, A. D.: Motional Narrowing and Other Effects in the Q Branch of HD, Can. J. Phys., 51, 36-39,, 1973.

Donovan, D. P., Whiteway, J. A., and Carswell, A. I.: Correction for nonlinear photon-counting effects in lidar systems, Appl. Opt., 32, 6742-6753, 1993.

Fally, S., Vandaele, A., Carleer, M., Hermans, C., Jenouvrier, A., Mérienne, M.-F., Coquart, B., and Colin, R.: Fourier Transform Spectroscopy of the O2 Herzberg Bands. III. Absorption Cross Sections of the Collision-Induced Bands and of the Herzberg Continuum, J. Molecular Spectr., 204, 10-20, 2000.

Falsini, P., Pini, R., Salimbeni, R., Vannini, M., Haider, A., and Buffa, R.: Simple and efficient H2 Raman conversion of a XeCl laser with a variable numerical aperture coupling geometry, Optics Communications, 53, 421-424, 1985.

Fishman, J., Watson, C. E., Larsen, J. C., and Logan, J. A.: Distribution of tropospheric ozone determined from satellite data, J. Geophys. Res.-Atmos., 95, 3599-3617, doi:10.1029/JD095iD04p03599, 1990.

Fix, A., Wirth, M., Meister, A., Ehret, G., Pesch, M., and Weidauer, D.: Tunable ultraviolet optical parametric oscillator for differential absorption lidar measurements of tropospheric ozone, Appl. Phys. B, 75, 153-163, doi:10.1007/s00340-002-0964-y, 2002.

Fromzel, V., Prasad, C., Petrosyan, K., Liaw, Y., Yakshin, M., Shi, W., and De Young, R.: Tunable, Narrow Linewidth, High Repetition Frequency Ce:LiCAF Lasers Pumped by the Fourth Harmonic of a Diode-Pumped Nd:YLF Laser for Ozone DIAL Measurements, Advances in Optical and Photonic Devices, edited by: Ki Young Kim, ISBN: 978-953-7619-76-3, doi:10.5772/7142, 2010.

Galani, E., Balis, D., Zanis, P., Zerefos, C., Papayannis, A., Wernli, H., and Gerasopoulos, E.: Observations of stratosphereto-troposphere transport events over the eastern Mediterranean 
using a ground-based lidar system, J. Geophys. Res.-Atmos., 108, 8527, doi:10.1029/2002JD002596, 2003.

Godin, S., Mégie, G., and Pelon, J.: Systematic lidar measurements of the stratospheric ozone vertical distribution, Geophys. Res. Lett., 16, 547-550, doi:10.1029/GL016i006p00547, 1989.

Haner, D. and McDermid, I.: Stimulated Raman shifting of the Nd:YAG fourth harmonic (266 nm) in H2, HD, and D2, Quantum Electronics, IEEE J., 26, 1292-1298, 1990.

Heese, B., Godin, S., and Hauchecorne, A.: Forecast and simulation of stratospheric ozone filaments: A validation of a highresolution potential vorticity advection model by airborne ozone lidar measurements in winter 1998/1999, J. Geophys. Res.Atmos,, 106, 20011-20024, doi:10.1029/2000JD900818, 2001.

Heikes, B. G., Kok, G. L., Walega, J. G., and Lazrus, A. L.: H2O2, $\mathrm{O} 3$ and $\mathrm{SO} 2$ measurements in the lower troposphere over the eastern United States during fall, J. Geophys. Res.-Atmos., 92, 915-931, doi:10.1029/JD092iD01p00915, 1987.

IPCC: Climate Change 2007 - The Physical Science Basis: Working Group I Contribution to the Fourth Assessment Report of the IPCC, Climate Change 2007, Cambridge University Press, 2007.

Keckhut, P., McDermid, S., Swart, D., McGee, T., GodinBeekmann, S., Adriani, A., Barnes, J., Baray, J.-L., Bencherif, H., Claude, H., di Sarra, A. G., Fiocco, G., Hansen, G., Hauchecorne, A., Leblanc, T., Lee, C. H., Pal, S., Megie, G., Nakane, H., Neuber, R., Steinbrecht, W., and Thayer, J.: Review of ozone and temperature lidar validations performed within the framework of the Network for the Detection of Stratospheric Change, J. Environ. Monit., 6, 721-733, doi:10.1039/B404256E, 2004.

Komhyr, W. D., Barnes, R. A., Brothers, G. B., Lathrop, J. A., and Opperman, D. P.: Electrochemical concentration cell ozonesonde performance evaluation during STOIC 1989, J. Geophys. Res.Atmos., 100, 9231-9244, doi:10.1029/94JD02175, 1995.

Komine, H.: Stimulated vibrational Raman scattering in HD, Quantum Electronics, IEEE J., 22, 520-521, 1986.

Kovalev, V. A. and Eichinger, W. E.: Elastic Lidar: Theory, Practice, and Analysis Methods, Wiley-Interscience, 1st Edn., 2004.

Kuang, S., Burris, J., Newchurch, M., Johnson, S., and Long, S.: Differential Absorption Lidar to Measure Subhourly Variation of Tropospheric Ozone Profiles, Geoscience and Remote Sensing, Trans. on IEEE, 49, 557-571, 2011.

Kuang, S., Newchurch, M. J., Burris, J., and Liu, X.: Ground-based lidar for atmospheric boundary layer ozone measurements, Appl. Opt., 52, 3557-3566, 2013.

Lampton, M. and Bixler, J.: Counting efficiency of systems having both paralyzable and nonparalyzable elements, Rev. Scientific Instr., 56, 164-165, 1985.

Langford, A. O.: Stratosphere-troposphere exchange at the subtropical jet: Contribution to the tropospheric ozone budget at midlatitudes, Geophys. Res. Lett., 26, 2449-2452, doi:10.1029/1999GL900556, 1999.

Langford, A. O., Senff, C. J., Alvarez, R. J., Banta, R. M., and Hardesty, R. M.: Long-range transport of ozone from the Los Angeles Basin: A case study, Geophys. Res. Let., 37, L0687, doi:10.1029/2010GL042507, 2010.

Leblanc, T., McDermid, I. S., Hauchecorne, A., and Keckhut, P.: Evaluation of optimization of lidar temperature analysis algorithms using simulated data, J. Geophys. Res.-Atmos., 103, 6177-6187, doi:10.1029/97JD03494, 1998.
Lehman, J., Swinton, K., Bortnick, S., Hamilton, C., Baldridge, E., Eder, B., and Cox, B.: Spatio-temporal characterization of tropospheric ozone across the eastern United States, Atmos. Environ., 38, 4357-4369, 2004.

Lin, J.-T. and McElroy, M. B.: Impacts of boundary layer mixing on pollutant vertical profiles in the lower troposphere: Implications to satellite remote sensing, Atmos. Environ., 44, 17261739, 2010.

Malicet, J., Daumont, D., Charbonnier, J., Parisse, C., Chakir, A., and Brion, J.: Ozone UV spectroscopy, II. Absorption crosssections and temperature dependence, J. Atmos. Chem., 21, 263 273, doi:10.1007/BF00696758, 1995.

McDermid, I. S., Haner, D. A., Kleiman, M. M., Walsh, T. D., and White, M. L.: Differential absorption lidar systems for tropospheric and stratospheric ozone measurements, Optical Eng., 30, 22-30, doi:10.1117/12.55768, 1991.

McDermid, I. S., Beyerle, G., Haner, D. A., and Leblanc, T.: Redesign and improved performance of the tropospheric ozone lidar at the jet propulsion laboratory table mountain facility, Appl. Opt., 41, 7550-7555, 2002.

McDonnell, W. F., Abbey, D. E., Nishino, N., and Lebowitz, M. D.: Long-Term Ambient Ozone Concentration and the Incidence of Asthma in Nonsmoking Adults: The Ahsmog Study, Environ. Res., 80, 110-121, 1999.

McGee, T. J., Whiteman, D. N., Butler, J. J., Burris, J. F., and Ferrare, R. A.: STROZ LITE: Stratospheric Ozone Lidar Trailer Experiment, Optical Eng., 30, 31-39, doi:10.1117/12.55771, 1991.

McGee, T. J., Gross, M., Ferrare, R., Heaps, W., and Singh, U.: Raman dial measurements of stratospheric ozone in the presence of volcanic aerosols, Geophys. Res. Lett., 20, 955-958, doi:10.1029/93GL00751, 1993.

McGee, T. J., Gross, M. R., Singh, U. N., Butler, J. J., and Kimvilakani, P. E.: Improved stratospheric ozone lidar, Optical Eng., 34, 1421-1430, doi:10.1117/12.199883, 1995.

McGee, T. J., Twigg, L., Hoegy, W., Burris, J. F., Heaps, W. S., Sumnicht, G., and Hostetler, C. A.: AROTAL: results from two arctic campaigns, Proc. SPIE, 5653, 121-129, doi:10.1117/12.578959, 2005.

Measures, R. M.: Laser Remote Sensing: Fundamentals and Applications, Wiley, New York, 1983.

Megie, G., Allain, J. Y., Chanin, M. L., and Blamont, J. E.: Vertical profile of stratospheric ozone by lidar sounding from the ground, Nature, 270, 329-331, doi:10.1038/270329a0, 1977.

Megie, G. J., Ancellet, G., and Pelon, J.: Lidar measurements of ozone vertical profiles, Appl. Opt., 24, 3454-3463, 1985.

Menzies, R. T. and Shumate, M. S.: Tropospheric ozone distributions measured with an airborne laser absorption spectrometer, J. Geophys. Res.-Ocean., 83, 4039-4043, doi:10.1029/JC083iC08p04039, 1978.

Milton, M., Ancellet, G., Apituley, A., Bösenberg, J., Carnuth, W., Castagnoli, F., Trickl, T., Edner, H., Stefanutti, L., Schaberl, T., Sunesson, A., and Weitkamp, C.: Raman-shifted laser sources suitable for differential-absorption lidar measurements of ozone in the troposphere, Appl. Phys. B, 66, 105-113, doi:10.1007/s003400050363, 1998.

Milton, M. J. T. and Woods, P. T.: Pulse averaging methods for a laser remote monitoring system using atmospheric backscatter, Appl. Opt., 26, 2598-2603, 1987. 
Mollenauer, L., White, J., and Pollock, C.: Stimulated Raman scattering, vol. 59 of Topics in Applied Physics, doi:10.1007/3-54055571-4_4, 1992.

Morris, G. A., Ford, B., Rappenglück, B., Thompson, A. M., Mefferd, A., Ngan, F., and Lefer, B.: An evaluation of the interaction of morning residual layer and afternoon mixed layer ozone in Houston using ozonesonde data, Atmos. Environ., 44, 40244034, 2010.

Murray, E. R., Powell, D. D., and van der Laan, J. E.: Measurement of average atmospheric temperature using a $\mathrm{CO} 2$ laser radar, Appl. Opt., 19, 1794-1797, 1980.

Murray, J. and Javan, A.: Effects of collisions on Raman line profiles of hydrogen and deuterium gas, J. Molecular Spectr., 42, 1-26, 1972.

NCADAC: The National Climate Assessment and Development Advisory Committee (NCADAC) Draft Climate Assessment Report, available at: http://ncadac.globalchange.gov/ (last access: 30 March 2014), 2013.

Newchurch, M. J., Ayoub, M. A., Oltmans, S., Johnson, B., and Schmidlin, F. J.: Vertical distribution of ozone at four sites in the United States, J. Geophys. Res.-Atmos., 108, ACH 9-1-ACH 917, doi:10.1029/2002JD002059, 2003.

Oltmans, S. J. and Komhyr, W. D.: Surface ozone distributions and variations from 1973-1984: Measurements at the NOAA Geophysical Monitoring for Climatic Change Baseline Observatories, J. Geophys. Res.-Atmos., 91, 5229-5236, doi:10.1029/JD091iD04p05229, 1986.

Oltmans, S. J., Levy, H., Harris, J. M., Merrill, J. T., Moody, J. L., Lathrop, J. A., and Cuevas, E.: Summer and spring ozone profiles over the North Atlantic from ozonesonde measurements, J. Geophys. Res.-Atmos., 101, 29179-29200, doi:10.1029/96JD01713, 1996.

Papayannis, A., Ancellet, G., Pelon, J., and Mégie, G.: Multiwavelength lidar for ozone measurements in the troposphere and the lower stratosphere, Appl. Opt., 29, 467-476, 1990.

Pelon, J. and Mégie, G.: Ozone monitoring in the troposphere and lower stratosphere: Evaluation and operation of a groundbased lidar station, J. Geophys. Res.-Ocean., 87, 4947-4955, doi:10.1029/JC087iC07p04947, 1982.

Proffitt, M. H. and Langford, A. O.: Ground-based differential absorption lidar system for day or night measurements of ozone throughout the free troposphere, Appl. Opt., 36, 2568-2585, 1997.

Puzak, J. C.: The EPA's Role in the Quality Assurance of Ambient Air Pollutant Measurements, American Society for Testing and Materials (ASTM), 1987.

Reiter, E. R.: Stratospheric-tropospheric exchange processes, Rev. Geophys., 13, 459-474, doi:10.1029/RG013i004p00459, 1975.

Savitzky, A. and Golay, M. J. E.: Smoothing and Differentiation of Data by Simplified Least Squares Procedures, Anal. Chem., 36, 1627-1639, doi:10.1021/ac60214a047, 1964.

Sawamura, P., Müller, D., Hoff, R. M., Hostetler, C. A., Ferrare, R. A., Hair, J. W., Rogers, R. R., Anderson, B. E., Ziemba, L. D., Beyersdorf, A. J., Thornhill, K. L., Winstead, E. L., and Holben, B. N.: Aerosol optical and microphysical retrievals from a hybrid multiwavelength lidar data set - DISCOVER-AQ 2011, Atmos. Meas. Tech., 7, 3095-3112, doi:10.5194/amt-7-3095-2014, 2014.
Schumann, U. and Huntrieser, H.: The global lightning-induced nitrogen oxides source, Atmos. Chem. Phys., 7, 3823-3907, doi:10.5194/acp-7-3823-2007, 2007.

Senff, C. J., Alvarez, R. J., Hardesty, R. M., Banta, R. M., and Langford, A. O.: Airborne lidar measurements of ozone flux downwind of Houston and Dallas, J. Geophys. Res.-Atmos., 115, D20307, doi:10.1029/2009JD013689, 2010.

Shen, Y. R. and Bloembergen, N.: Theory of Stimulated Brillouin and Raman Scattering, Phys. Rev., 137, A1787-A1805, doi:10.1103/PhysRev.137.A1787, 1965.

Smit, H. G. J., Straeter, W., Johnson, B. J., Oltmans, S. J., Davies, J., Tarasick, D. W., Hoegger, B., Stubi, R., Schmidlin, F. J., Northam, T., Thompson, A. M., Witte, J. C., Boyd, I., and Posny, F.: Assessment of the performance of ECC-ozonesondes under quasi-flight conditions in the environmental simulation chamber: Insights from the Juelich Ozone Sonde Intercomparison Experiment (JOSIE), J. Geophys. Res.-Atmos., 112, D19306, doi:10.1029/2006JD007308, 2007.

Stark, G., Smith, P. L., Rufus, J., Thorne, A. P., Pickering, J. C., and Cox, G.: High-resolution photoabsorption cross-section measurements of SO2 at $295 \mathrm{~K}$ between 198 and $220 \mathrm{~nm}$, J. Geophys. Res.-Planets, 104, 16585-16590, doi:10.1029/1999JE001022, 1999.

Stefanutti, L., Castagnoli, F., Del Guasta, M., Morandi, M., Sacco, V., Zuccagnoli, L., Godin, S., Megie, G., and Porteneuve, J.: The antarctic ozone LIDAR system, Appl. Phys. B, 55, 3-12, doi:10.1007/BF00348606, 1992.

Steinbrecht, W., Claude, H., Schönenborn, F., McDermid, I. S., Leblanc, T., Godin, S., Song, T., Swart, D. P. J., Meijer, Y. J., Bodeker, G. E., Connor, B. J., Kämpfer, N., Hocke, K., Calisesi, Y., Schneider, N., de la Noë, J., Parrish, A. D., Boyd, I. S., Brühl, C., Steil, B., Giorgetta, M. A., Manzini, E., Thomason, L. W., Zawodny, J. M., McCormick, M. P., Russell, J. M., Bhartia, P. K., Stolarski, R. S., and Hollandsworth-Frith, S. M.: Long-term evolution of upper stratospheric ozone at selected stations of the Network for the Detection of Stratospheric Change (NDSC), J. Geophys. Res.-Atmos., 111, D10308, doi:10.1029/2005JD006454, 2006.

Stevenson, D. S., Young, P. J., Naik, V., Lamarque, J.-F., Shindell, D. T., Voulgarakis, A., Skeie, R. B., Dalsoren, S. B., Myhre, G., Berntsen, T. K., Folberth, G. A., Rumbold, S. T., Collins, W. J., MacKenzie, I. A., Doherty, R. M., Zeng, G., van Noije, T. P. C., Strunk, A., Bergmann, D., Cameron-Smith, P., Plummer, D. A., Strode, S. A., Horowitz, L., Lee, Y. H., Szopa, S., Sudo, K., Nagashima, T., Josse, B., Cionni, I., Righi, M., Eyring, V., Conley, A., Bowman, K. W., Wild, O., and Archibald, A.: Tropospheric ozone changes, radiative forcing and attribution to emissions in the Atmospheric Chemistry and Climate Model Intercomparison Project (ACCMIP), Atmos. Chem. Phys., 13, 3063-3085, doi:10.5194/acp-13-3063-2013, 2013.

Stohl, A., Bonasoni, P., Cristofanelli, P., Collins, W., Feichter, J., Frank, A., Forster, C., Gerasopoulos, E., Gäggeler, H., James, P., Kentarchos, T., Kromp-Kolb, H., Krüger, B., Land, C., Meloen, J., Papayannis, A., Priller, A., Seibert, P., Sprenger, M., Roelofs, G. J., Scheel, H. E., Schnabel, C., Siegmund, P., Tobler, L., Trickl, T., Wernli, H., Wirth, V., Zanis, P., and Zerefos, C.: Stratosphere-troposphere exchange: A review, and what we have learned from STACCATO, J. Geophys. Res.-Atmos., 108, 8516, doi:10.1029/2002JD002490, 2003. 
Thompson, A. M., Witte, J. C., Oltmans, S. J., Schmidlin, F. J., Logan, J. A., Fujiwara, M., Kirchhoff, V. W. J. H., Posny, F., Coetzee, G. J. R., Hoegger, B., Kawakami, S., Ogawa, T., Fortuin, J. P. F., and Kelder, H. M.: Southern Hemisphere Additional Ozonesondes (SHADOZ) 1998-2000 tropical ozone climatology 2. Tropospheric variability and the zonal wave-one, J. Geophys. Res.-Atmos., 108, 8241, doi:10.1029/2002JD002241, 2003.

Thompson, A. M., Yorks, J. E., Miller, S. K., Witte, J. C., Dougherty, K. M., Morris, G. A., Baumgardner, D., Ladino, L., and Rappenglück, B.: Tropospheric ozone sources and wave activity over Mexico City and Houston during MILAGRO/Intercontinental Transport Experiment (INTEX-B) Ozonesonde Network Study, 2006 (IONS-06), Atmos. Chem. Phys., 8, 5113-5125, doi:10.5194/acp-8-5113-2008, 2008.

Trickl, T., Cooper, O. R., Eisele, H., James, P., Mücke, R., and Stohl, A.: Intercontinental transport and its influence on the ozone concentrations over central Europe: Three case studies, J. Geophys. Res.-Atmos., 108, 8530, doi:10.1029/2002JD002735, 2003.

Trickl, T., Bärtsch-Ritter, N., Eisele, H., Furger, M., Mücke, R., Sprenger, M., and Stohl, A.: High-ozone layers in the middle and upper troposphere above Central Europe: potential import from the stratosphere along the subtropical jet stream, Atmos. Chem. Phys., 11, 9343-9366, doi:10.5194/acp-11-9343-2011, 2011.

Tzortzakis, S., Tsaknakis, G., Papayannis, A., and Serafetinides, A.: Investigation of the spatial profile of stimulated Raman scattering beams in D2 and $\mathrm{H} 2$ gases using a pulsed Nd:YAG laser at 266 nm, Appl. Phys. B, 79, 71-75, doi:10.1007/s00340-004-1508-4, 2004.

Uchino, O., Maeda, M., Kohno, J., Shibata, T., Nagasawa, C., and Hirono, M.: Observation of stratospheric ozone layer by a $\mathrm{XeCl}$ laser radar, Appl. Phys. Lett., 33, 807-809, 1978.

Uchino, O., Tokunaga, M., Maeda, M., and Miyazoe, Y.: Differential-absorption-lidar measurement of tropospheric ozone with excimer-Raman hybrid laser, Opt. Lett., 8, 347-349, 1983.

Uchino, O., Sakai, T., Nagai, T., Morino, I., Maki, T., Deushi, M., Shibata, K., Kajino, M., Kawasaki, T., Akaho, T., Takubo, S., Okumura, H., Arai, K., Nakazato, M., Matsunaga, T., Yokota, T., Kawakami, S., Kita, K., and Sasano, Y.: DIAL measurement of lower tropospheric ozone over Saga $\left(33.24^{\circ} \mathrm{N}, 130.29^{\circ}\right.$ E), Japan, and comparison with a chemistry-climate model, Atmos. Meas. Tech., 7, 1385-1394, doi:10.5194/amt-7-1385-2014, 2014.
US Standard: U.S. standard atmosphere, 1976/[adopted by the United States Committee on Extension to the Standard Atmosphere], National Oceanic and Amospheric Administration. U.S. Govt. Print. Off., Washington, 1976.

Uthe, E. E., Livingston, J. M., and Nielsen, N. B.: Airborne Lidar Mapping of Ozone Concentrations During the Lake Michigan Ozone Study, J. Air Waste Manage. Assoc., 42, 1313-1318, doi:10.1080/10473289.1992.10467078, 1992.

Veselovskii, I. and Barchunov, B.: Excimer-laser-based lidar for tropospheric doi:10.1007/s003400050756, 1999.

Viezee, W., Johnson, W. B., and Singh, H. B.: Stratospheric ozone in the lower troposphere - II. Assessment of downward flux and ground-level impact, Atmospheric Environ., (1967), 17, 19791993, 1983.

Weitkamp, C. (Ed.): Lidar: Range-Resolved Optical Remote Sensing of the Atmosphere, Springer, 2006.

Witkowicz, T. and May, A. D.: Collisional effects in compressed HD, Canadian J. Phys., 54, 575-583, 1976.

Yorks, J. E., Thompson, A. M., Joseph, E., and Miller, S. K.: The variability of free tropospheric ozone over Beltsville, Maryland (39N, 77W) in the summers 2004-2007, Atmos. Environ., 43, 1827-1838, 2009.

Yuan, T., Remer, L. A., Bian, H., Ziemke, J. R., Albrecht, R., Pickering, K. E., Oreopoulos, L., Goodman, S. J., Yu, H., and Allen, D. J.: Aerosol indirect effect on tropospheric ozone via lightning, J. Geophys. Res., 117, D18213, doi:10.1029/2012JD017723, 2012.

Ziemke, J. R., Chandra, S., Duncan, B. N., Froidevaux, L., Bhartia, P. K., Levelt, P. F., and Waters, J. W.: Tropospheric ozone determined from Aura OMI and MLS: Evaluation of measurements and comparison with the Global Modeling Initiative's Chemical Transport Model, J. Geophys. Res.-Atmos., 111, D19303, doi:10.1029/2006JD007089, 2006. 